\title{
Conceptual Model Update of Mercury Sources and Flux at $Y-12$ and Upper East Fork Poplar Creek, Oak Ridge, Tennessee
}

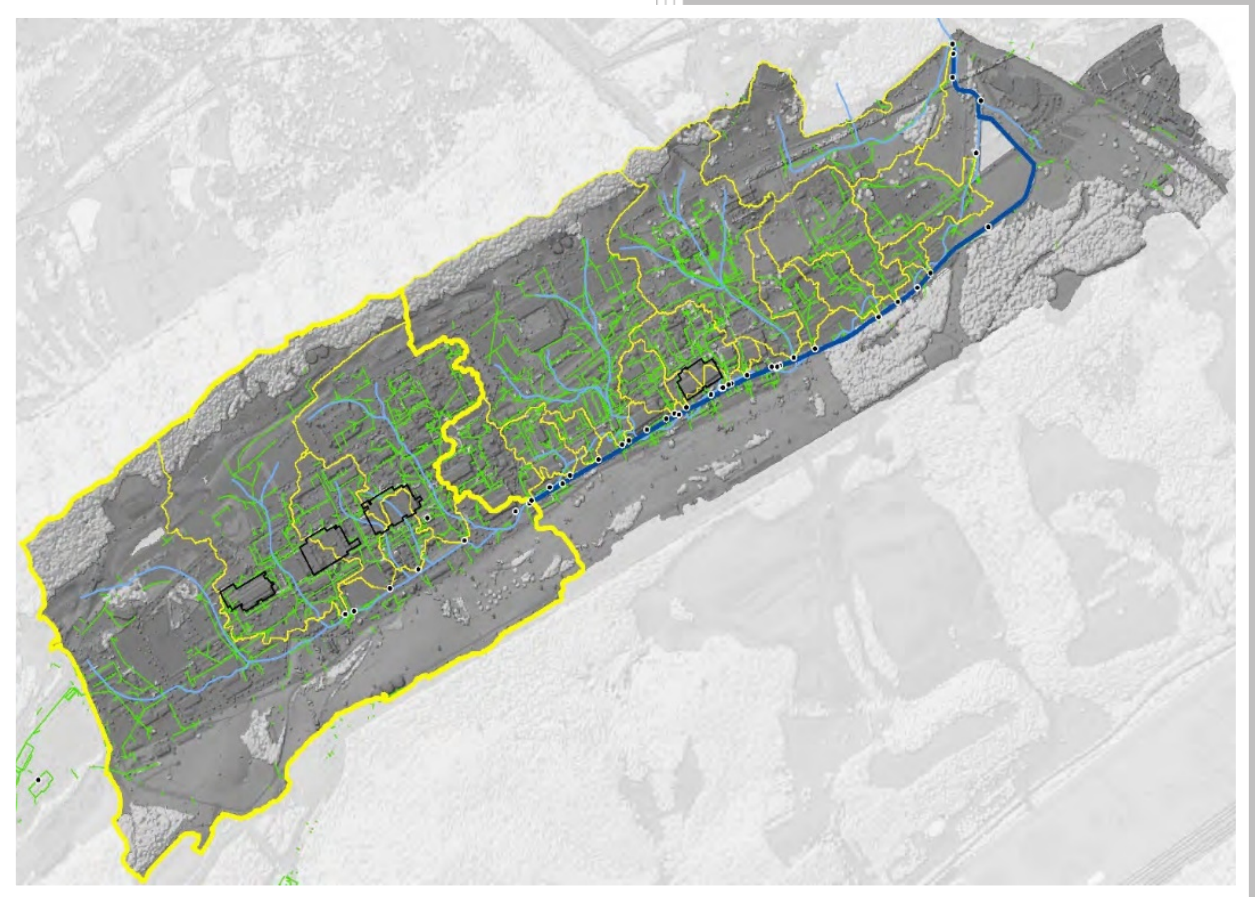

Approved for public release.

C. R. DeRolph

T. J. Mathews

S. C. Brooks

S. S. Nair

M. J. Peterson

Distribution is unlimited.

December 2020 


\title{
DOCUMENT AVAILABILITY
}

Reports produced after January 1, 1996, are generally available free via US Department of Energy (DOE) SciTech Connect.

Website www.osti.gov

Reports produced before January 1, 1996, may be purchased by members of the public from the following source:

\author{
National Technical Information Service \\ 5285 Port Royal Road \\ Springfield, VA 22161 \\ Telephone 703-605-6000 (1-800-553-6847) \\ TDD 703-487-4639 \\ Fax 703-605-6900 \\ E-mail info@ntis.gov \\ Website http://classic.ntis.gov/
}

Reports are available to DOE employees, DOE contractors, Energy Technology Data Exchange representatives, and International Nuclear Information System representatives from the following source:

Office of Scientific and Technical Information

PO Box 62

Oak Ridge, TN 37831

Telephone 865-576-8401

Fax 865-576-5728

E-mail reports@osti.gov

Website http://www.osti.gov/contact.html

This report was prepared as an account of work sponsored by an agency of the United States Government. Neither the United States Government nor any agency thereof, nor any of their employees, makes any warranty, express or implied, or assumes any legal liability or responsibility for the accuracy, completeness, or usefulness of any information, apparatus, product, or process disclosed, or represents that its use would not infringe privately owned rights. Reference herein to any specific commercial product, process, or service by trade name, trademark, manufacturer, or otherwise, does not necessarily constitute or imply its endorsement, recommendation, or favoring by the United States Government or any agency thereof. The views and opinions of authors expressed herein do not necessarily state or reflect those of the United States Government or any agency thereof. 
Environmental Sciences Division

\title{
CONCEPTUAL MODEL UPDATE OF MERCURY SOURCES AND FLUX AT Y-12 AND UPPER EAST FORK POPLAR CREEK, OAK RIDGE, TENNESSEE
}

\author{
C. R. DeRolph \\ T. J. Mathews \\ S. C. Brooks \\ S. S. Nair \\ M. J. Peterson
}

December 2020

Prepared by

OAK RIDGE NATIONAL LABORATORY

Oak Ridge, TN 37831-6283

managed by

UT-BATTELLE, LLC

for the

US DEPARTMENT OF ENERGY

under contract DE-AC05-00OR22725 



\section{CONTENTS}

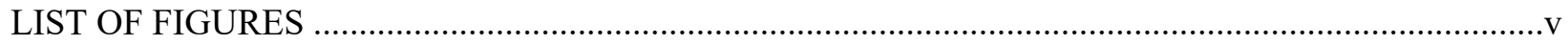

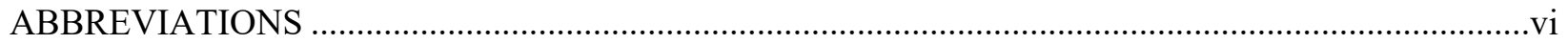

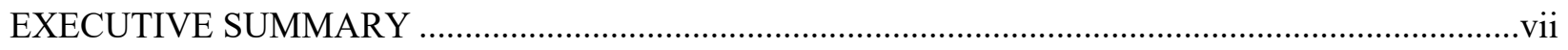

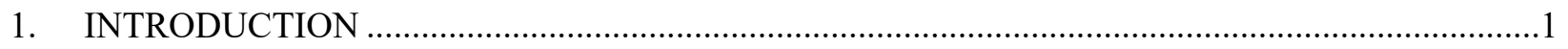

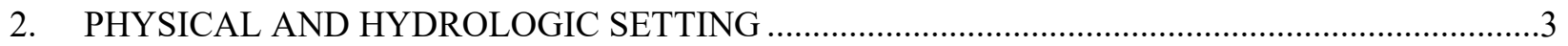

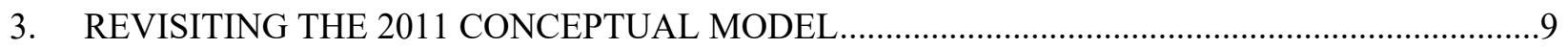

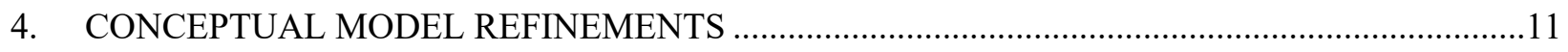

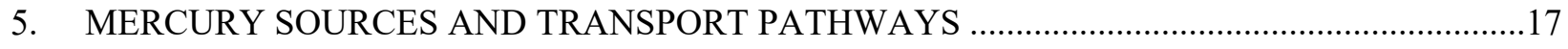

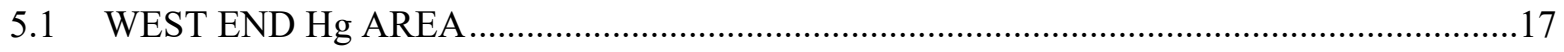

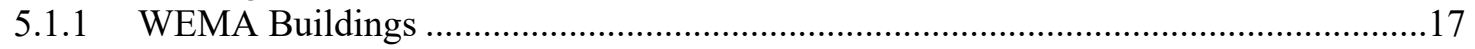

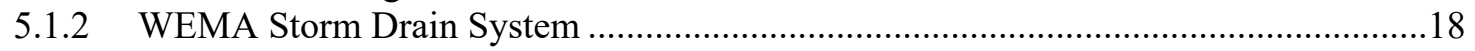

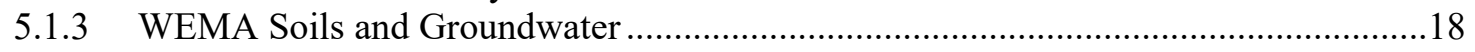

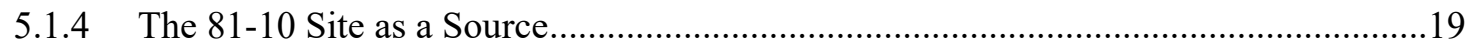

5.1.5 WEMA Surface Soil Erosion and Wet-Weather Export...........................................20

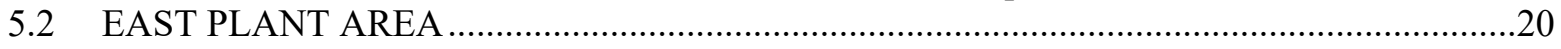

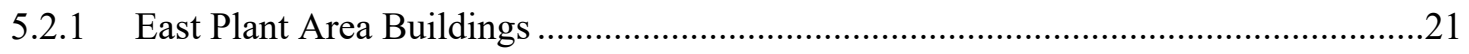

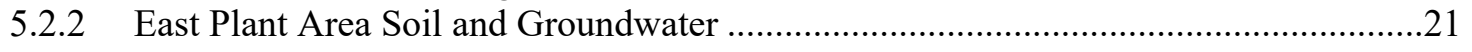

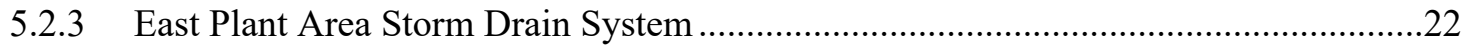

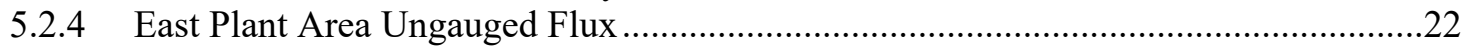

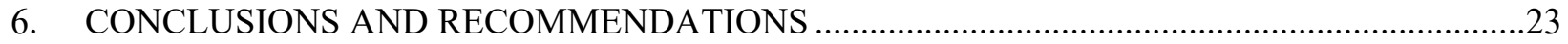

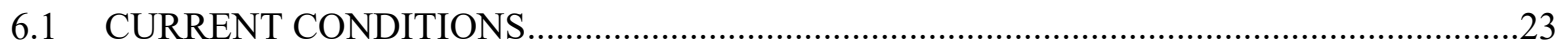

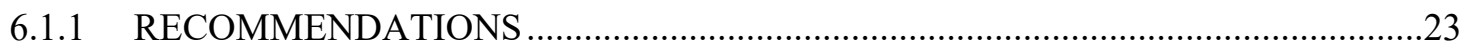

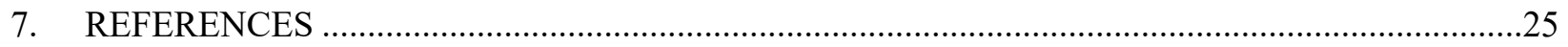




\section{LIST OF FIGURES}

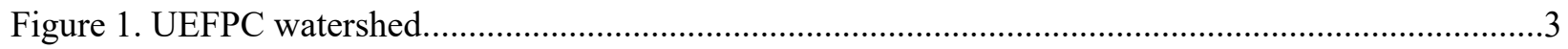

Figure 2. WEMA

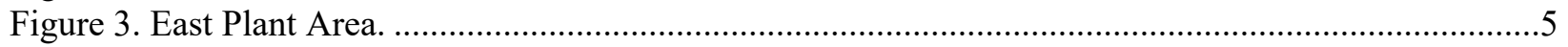

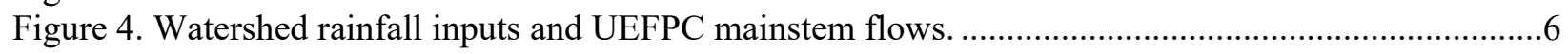

Figure 5. Outfall flows during baseflow and stormflow conditions. ...................................................

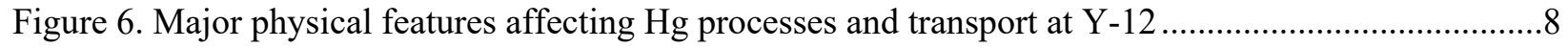

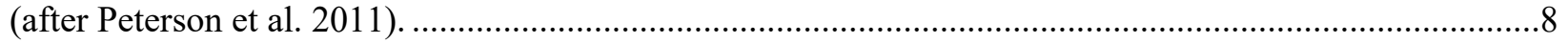

Figure 7. Updated conceptual model diagram from Peterson et al. (2011)............................................10

Figure 8. Total $\mathrm{Hg}$ concentrations over time at key monitoring locations. ..............................................12

Figure 9. Annual $\mathrm{Hg}$ flux over time at key monitoring locations. .........................................................13

Figure 10. Average total $\mathrm{Hg}$ flux from 2009 to 2018 at key monitoring locations. ................................14

Figure 11. Mercury concentrations for mainstem and outfalls during baseflow and stormflow

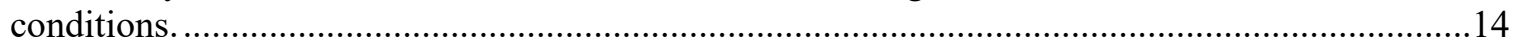

Figure 12. Methylmercury concentration over time at key monitoring locations. ...................................15

Figure 13. Methylmercury flux over time at key monitoring locations..................................................16 


\section{ABBREVIATIONS}

BSWTS Big Springs Water Treatment System

CMTS Central Mercury Treatment System

DOE US Department of Energy

D\&D decontamination and decommissioning

EFK East Fork Poplar Creek kilometer

EFPC East Fork Poplar Creek

$\mathrm{Hg}$

$\operatorname{Hg}(0)$

$\mathrm{Hg}(\mathrm{II})$

$\mathrm{MeHg}$

MTF

$\mathrm{N} / \mathrm{S}$

mercury

elemental mercury

inorganic mercury

methylmercury

Mercury Treatment Facility

north/south

$\mathrm{OF}$

Outfall

RMPE Reduction of Mercury in Plant Effluent Program

UEFPC Upper East Fork Poplar Creek

WEMA West End Mercury Area

Y-12 Y-12 National Security Complex 


\section{EXECUTIVE SUMMARY}

The interactions between the key processes that control the fate and transport of mercury $(\mathrm{Hg})$ in the sediments, groundwater, and stream water within the Y-12 National Security Complex (Y-12) in Oak Ridge, Tennessee are complex, and many aspects are not well understood. In contaminated environments such as Y-12, conceptual models are frequently developed to aid in visualizing and understanding the dynamic nature of the hydrologic, geochemical, and physical environment. These conceptual models integrate data in an internally consistent manner to understand processes that control the fate and transport of contaminants. Over the past few decades of environmental investigation at Y-12, a number of conceptual models have been developed to identify and define various technical processes at various scales.

The main purpose of the activities described in this report is to update the 2011 conceptual model for Upper East Fork Poplar Creek using the most recent Hg concentration and flux data and informed scientific interpretation. Emphasis was placed on improving the previous model by implementing a more detailed spatial and temporal approach to visualize transport pathways in the watershed and trends in flux and concentration over time, and to compare baseflow and stormflow system dynamics. Detailed descriptions of historical and current $\mathrm{Hg}$ sources and transport pathways are also provided for the east and west ends of the facility. This conceptual model will allow the US Department of Energy to evaluate past and present remedial activities and provide a strong technical basis for prioritizing and optimizing remedial responses in a cost-effective and efficient manner.

Twenty years ago, Hg flux from Outfall (OF) 200 at the headwaters of East Fork Poplar Creek represented approximately $20 \%$ of the overall flux leaving Y-12. By the time of the 2011 conceptual model report, that percentage had increased to $70 \%-80 \%$. Flux estimates compiled for this report using data from 2009 to 2018 show that OF200 accounted for roughly $60 \%$ of the flux leaving Y-12. The relative role of the four storm drain conduits to OF200 appeared similar to 2011, with OF163 being the greatest contributor to downstream flux. An increase in $\mathrm{Hg}$ concentrations and flux occurred throughout and downstream of west end storm drains in 2011 in response to a storm drain cleanout.

Leading up to the 2011 storm drain cleanout, annual baseflow flux was higher at OF200A6 than at Station 17. From 2011 to 2018, the trend reversed with concentrations and flux being higher at Station 17 than at OF200A6. A spike in concentrations occurred in July 2018, potentially due to a one-time influx of $\mathrm{Hg}$ that occurred during COLEX decontamination and decommissioning activities at Y-12.

This report includes recommendations for improving our conceptual understanding of $\mathrm{Hg}$ sources, transport pathways, and flux at Y-12. Important recommendations include further evaluation of transport pathways, concurrent measurement of $\mathrm{Hg}$ concentration and flux under baseflow and stormflow conditions at multiple sites, and research to understand the connections among periphyton and methylmercury concentration, bioavailability, and bioaccumulation.

Ongoing facility decontamination and decommissioning efforts, site characterization, remedial actions, and research are facilitating the collection of new $\mathrm{Hg}$ data at Y-12. The conceptual model update provided herein takes advantage of the extensive recent $\mathrm{Hg}$ sampling to provide an updated assessment of $\mathrm{Hg}$ mass balance and support a refined understanding of $\mathrm{Hg}$ behavior at or near Y-12. This assessment should assist in future environmental management decisions and in mitigating the impacts of $\mathrm{Hg}$ on the surrounding environment. 


\section{INTRODUCTION}

Releases of mercury (Hg) during operations at the Y-12 National Security Complex (Y-12) during the 1950 s and early 1960s resulted in contamination of soil and groundwater within the facility, and subsequent transport from these sources resulted in contamination of East Fork Poplar Creek (EFPC) and the surrounding floodplain. Remediation efforts, which began in the 1980s, have reduced waterborne $\mathrm{Hg}$ concentrations within Y-12 and in the EFPC ecosystem, but elevated levels of Hg remain in the soil, sediment, water, and biota. The hydrologic, geochemical, and biotic interactions between the subsurface and surface water system processes that control the fate and transport of $\mathrm{Hg}$ near the facility are complex, and although significant progress has been made through monitoring and research, much is left to be understood.

Conceptual models are diagrams or narrative descriptions used to inform decision makers and the public. They are often used in environmental management to summarize the current state of understanding and highlight key knowledge gaps. Such models can help focus stakeholders on the key processes and factors important to effective decision-making and influence future monitoring, prioritization of further remedial actions, numerical modeling efforts, and decisions concerning the need for further research.

Importantly, conceptual models can provide clarity in understanding limited or complex data and can help identify data gaps and convey uncertainty. Conceptual models have been used to visualize and understand the complex $\mathrm{Hg}$ processes at Y-12; a compendium of historical conceptual models and diagrams used to describe the Hg situation at Y-12 and/or in EFPC was summarized by Peterson et al. (2011).

Since the conceptual model of primary Hg sources, transport pathways, and flux at Y-12 and upper EFPC (UEFPC, Figure 1) was developed in 2010 (Peterson et al. 2011), multiple actions have been conducted at Y-12 that have affected instream $\mathrm{Hg}$ transport and fate. A major storm drain cleanout within the West End Mercury Area (WEMA) was completed in 2011, and flow augmentation to the creek was discontinued in 2014. Both actions have resulted in major changes in $\mathrm{Hg}$ concentration, flux, and even the speciation of $\mathrm{Hg}$ in the creek. New surface water sampling sites have also been added in recent years as part of the UCOR (URS | CH2M Oak Ridge LLC) Water Resource Restoration Program, so a richer UEFPC surface water data set is available to use for conceptual model development. Finally, new spatial data sets derived from recently collected LiDAR data have been developed and can now be integrated into conceptual model development.

An update of the conceptual model for Hg within Y-12 and UEFPC is timely. First, as stated previously, a significant amount of new information is available to refine and update the model. Second, an understanding of current conditions can provide an important key baseline by which the performance of the future Mercury Treatment Facility (MTF) at Outfall (OF) 200 can be evaluated after it begins operating. A reevaluation of $\mathrm{Hg}$ source areas, processes, likely flow paths, and flux into the creek at Y-12 is needed for effective environmental management and site closure decision-making relative to $\mathrm{Hg}$ contamination. Furthermore, the US Department of Energy (DOE) is concerned that remediation and construction activities during decontamination and decommissioning (D\&D) could induce changes in subsurface flow paths, resulting in unintended short-term releases and increased $\mathrm{Hg}$ concentrations in surface water. D\&D efforts have been ongoing at Y-12 since the previous conceptual model report.

The primary objective of this update is to improve upon the previous model by implementing a more detailed spatial and temporal approach to visualize transport pathways in the watershed and trends in flux and concentration over time, and to compare baseflow and stormflow system dynamics. This work builds on numerous previous conceptual models aimed at understanding the $\mathrm{Hg}$ source and transport pathways at Y-12 and uses the previous conceptual model (Peterson et al. 2011) as a starting point. Using both historical and recent data, this report provides an evaluation of $\mathrm{Hg}$ mass balance and supports a refined 
understanding of $\mathrm{Hg}$ behavior at or near Y-12 to assist in environmental management. A general overview of watershed characteristics and history is presented, followed by a review of the previous conceptual model, model updates and refinements, detailed descriptions of historical and current $\mathrm{Hg}$ sources and transport pathways, and conclusions and recommendations. 


\section{PHYSICAL AND HYDROLOGIC SETTING}

Y-12 is an industrial facility that has operated since the 1940s and consists of buildings and infrastructure in Bear Creek Valley. Significant quantities of $\mathrm{Hg}$ have been released from the Y-12 facilities into the environment, including an estimated 193,000 kg to soil and 128,000 kg to EFPC by 1963 (ChemRisk 1999; Brooks and Southworth 2011). The major Hg use buildings and $\mathrm{Hg}$ treatment systems found within Y-12 in the context of transport pathways, outfalls, and underlying lithology are shown in Figures 1-3. Transport pathways may include historical stream and tributary channels, overland flow, process discharges, storm drains, and diffuse subsurface channels. Significant work was done for this report to geo-reference storm drain lines since the historic stream channels within the UEFPC watershed were piped and then filled during facility construction in the 1940s such that the stormwater infrastructure serves as the tributary system to UEFPC. A LiDAR digital elevation model of the UEFPC watershed was reconditioned to incorporate storm drain lines and historic stream channels into a surface model that could be used to estimate contributing drainage areas to outfalls for visualization and analysis of flux and transport of $\mathrm{Hg}$.

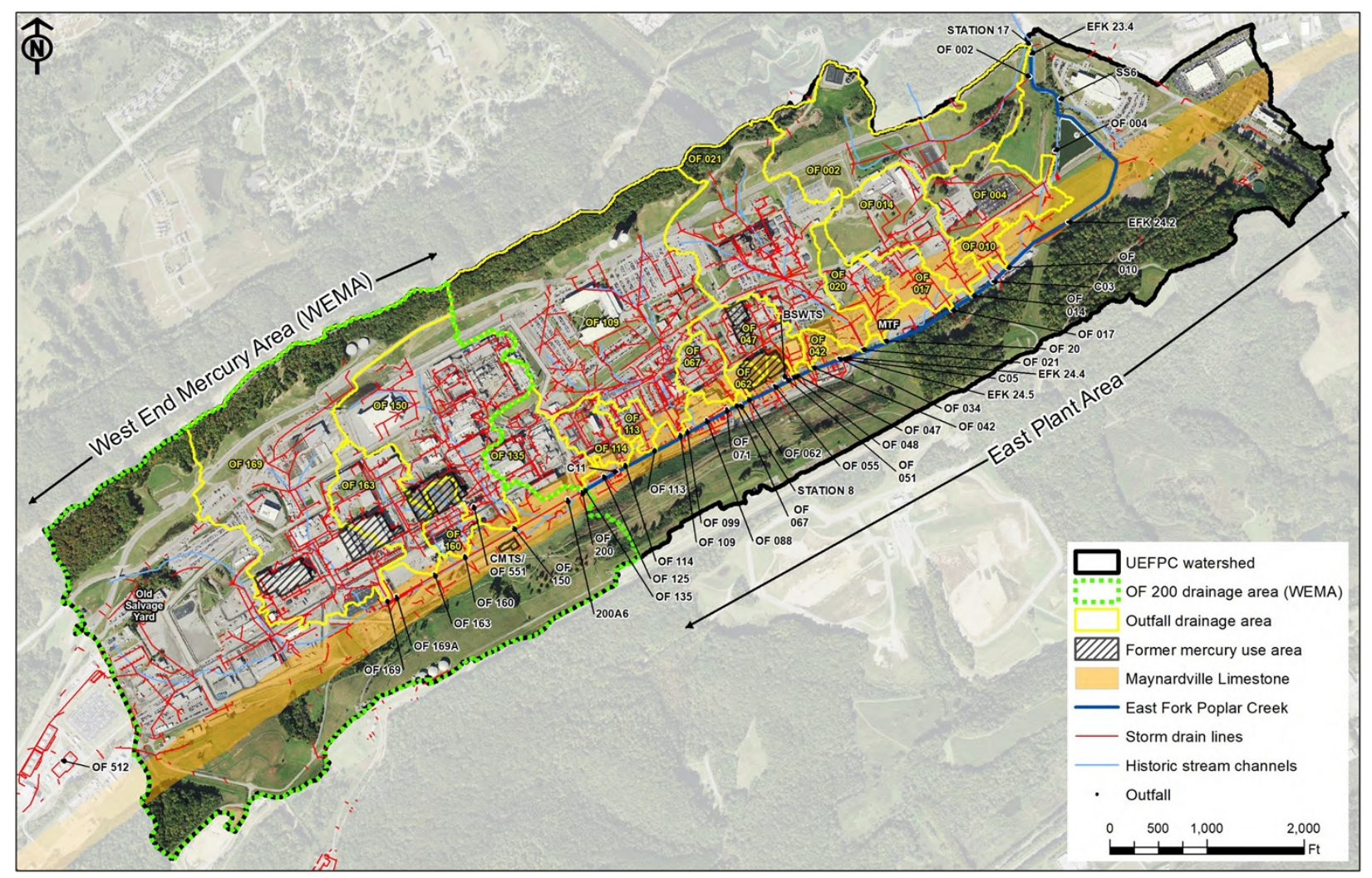

Figure 1. UEFPC watershed. All locations approximate, including outfall drainage area boundaries. 


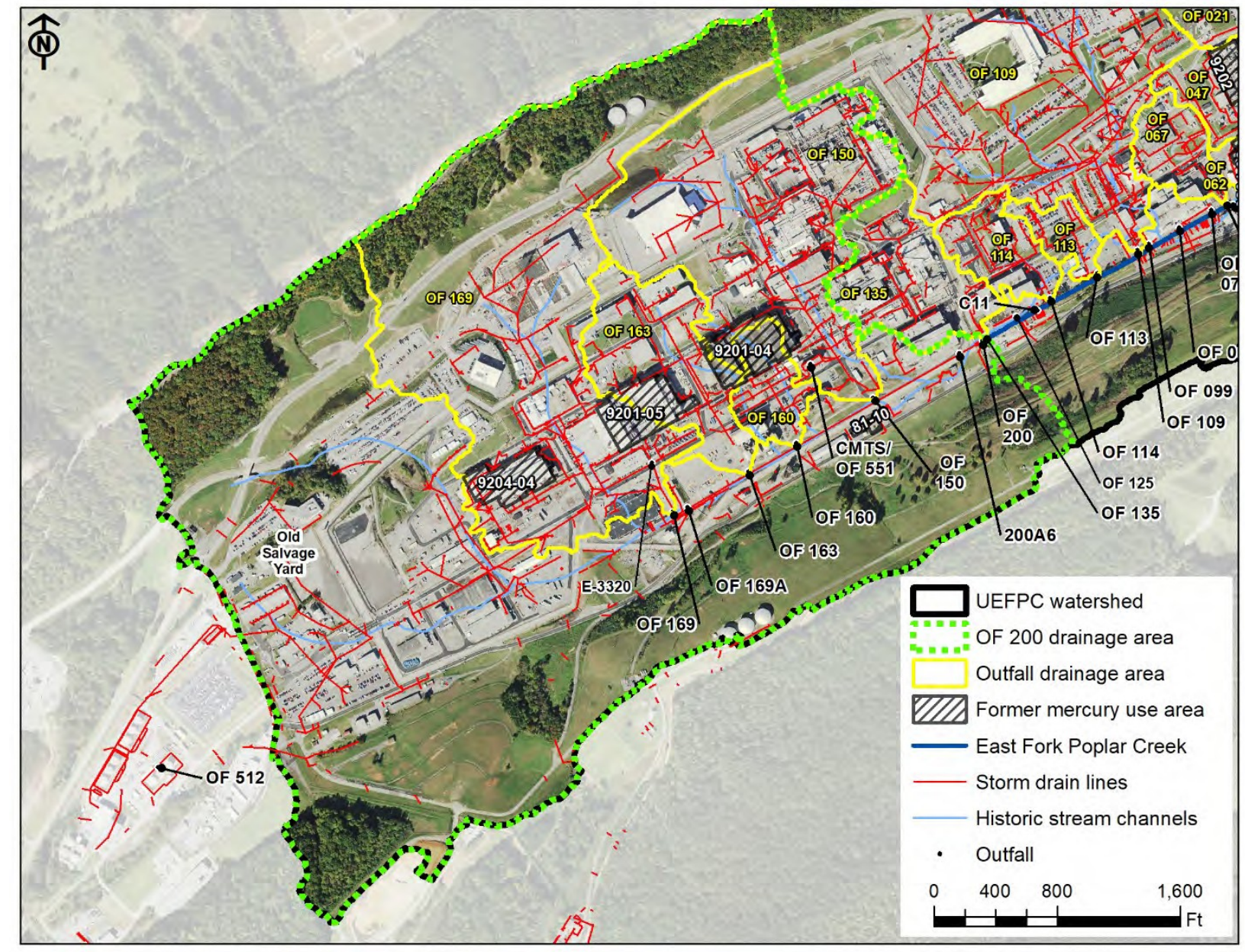

Figure 2. WEMA. 


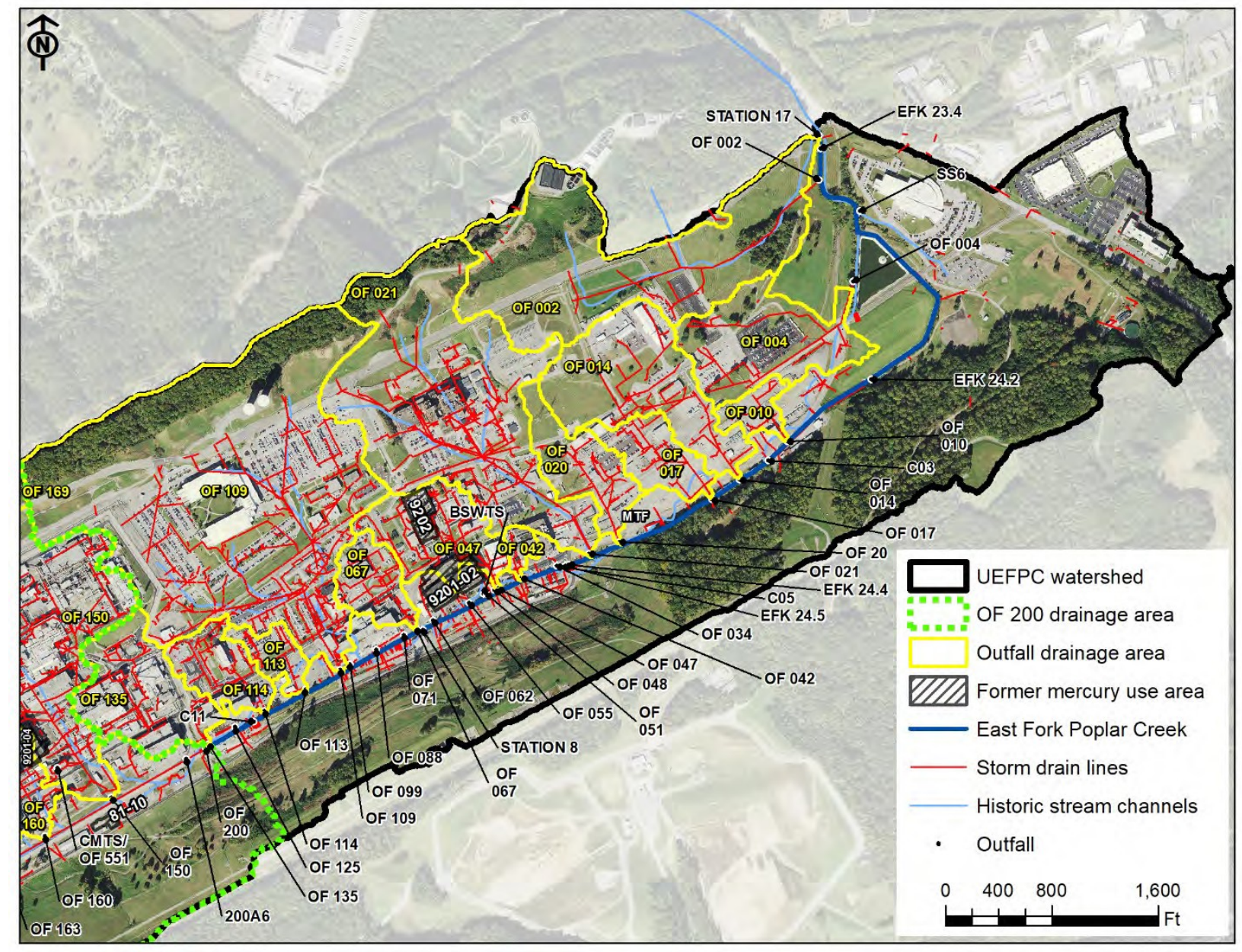

Figure 3. East Plant Area.

Because of the high level of impervious surface cover in the UEFPC watershed, the creek responds quickly to rainfall events and flows increase rapidly throughout the creek after rainfall (Figure 4). A visual review of creek flow response to different rainfall amounts indicates that in general, daily flows in the creek within the UEFPC watershed undergo a detectable increase when daily rainfall amounts exceed $0.5 \mathrm{in.}$ Thus, a daily rainfall cutoff of $0.5 \mathrm{in}$. was used to distinguish between baseflow and stormflow conditions for this report. Examination of the median daily flow at significant outfalls throughout the watershed compared with flows at Station 17 (Figure 5) shows that OF200A6 (which serves as an integration point for contamination leaving WEMA) contributes roughly $31 \%$ of the flow at Station 17 during baseflow conditions. OF150 and OF169A contribute the majority of flow at OF200A6 during both baseflow and stormflow. During stormflow conditions, discharge increases throughout the storm drain network and significant increases in contributions to flow at Station 17 are observed at major storm drain OF21 and OF109. 


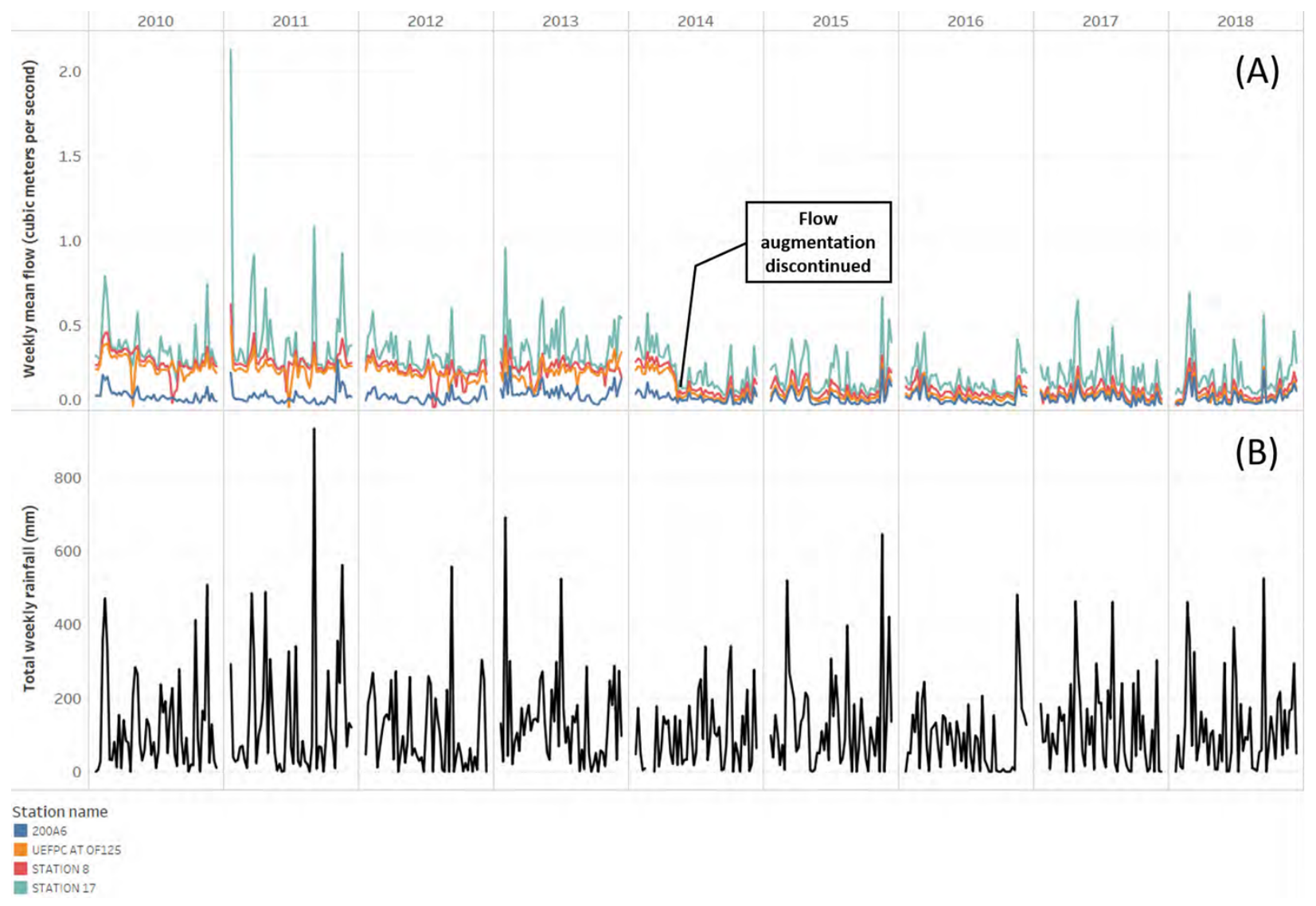

Figure 4. Watershed rainfall inputs and UEFPC mainstem flows. (A) Weekly average flows at OF200A6, UEFPC at OF125, Station 8, and Station 17; and (B) total weekly rainfall. 


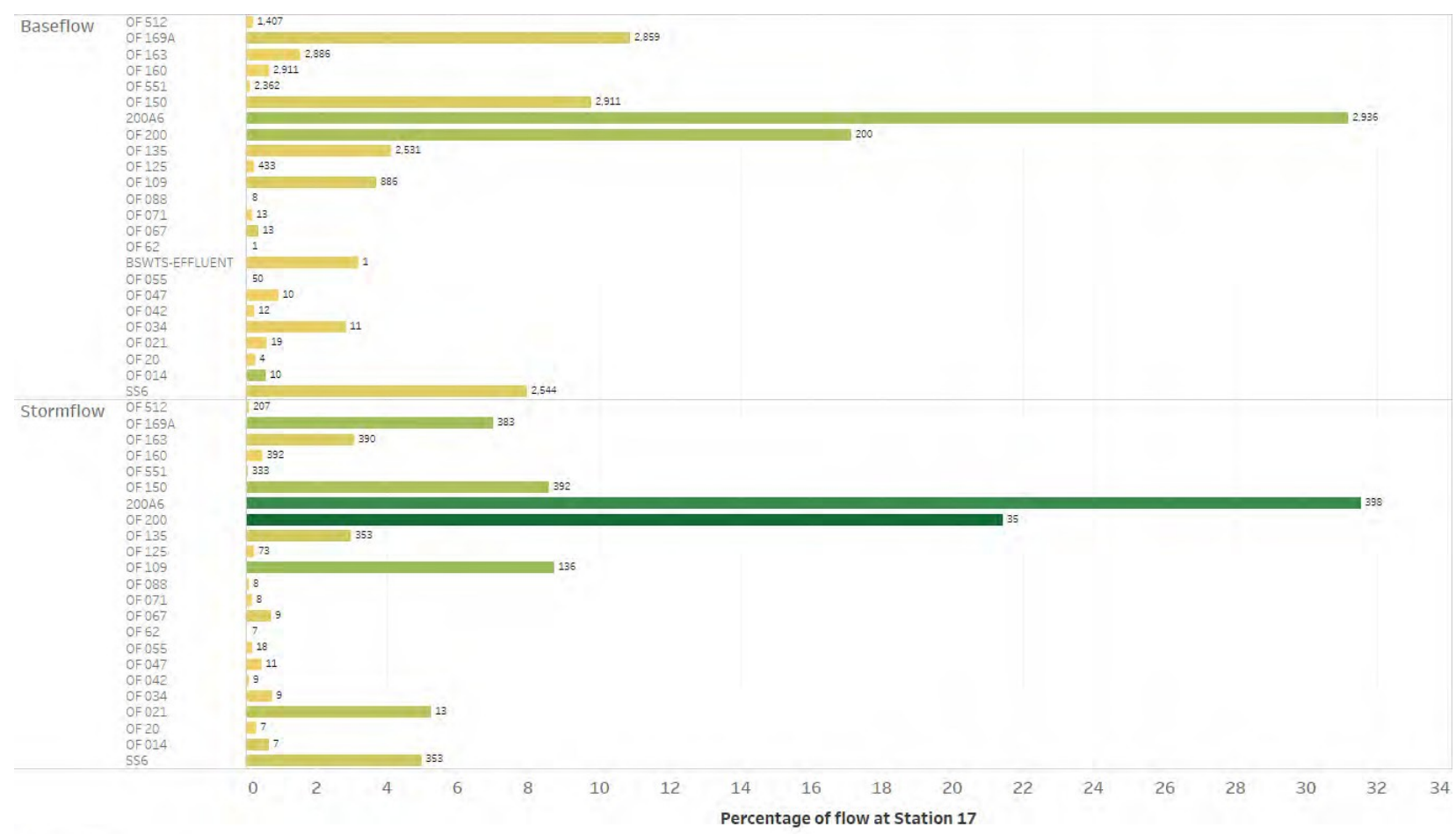

Median flow (cms)

$0.0000 \quad 0.2497$

Figure 5. Outfall flows during baseflow and stormflow conditions. Median daily baseflow and stormflow from 2010 to 2018 for significant outfalls in UEFPC watershed. Labels show count of data values used in calculation. Color of bars is coded to median daily flow.

Figure 6 shows a simplified graphic of the major physical features affecting $\mathrm{Hg}$ processes and transport at Y-12. The graphic depicts key features of subsurface physical structure and contaminant transport-release pathways within Y-12 and the UEFPC area. The subsurface beneath Y-12 consists of a layer of unconsolidated saprolite or fill overlying fractured and folded bedrock formations of shale and limestone that characterize the geology of the regional ridge and valley topography. The thickness of the unconsolidated material varies from a few feet to nearly $30 \mathrm{ft}$ in the north-central area of the complex. Most facilities in WEMA are located on the low-permeability Nolichucky Shale formations. The 81-10 site (Figure 2) and part of 9201-2 (Figure 3) lie on the much more permeable and karstic Maynardville Limestone (Figure 1). The groundwater level ranges from less than 5 to $10 \mathrm{ft}$ below the surface near UEFPC to more than 30 to $40 \mathrm{ft}$ below the surface in upland areas. 


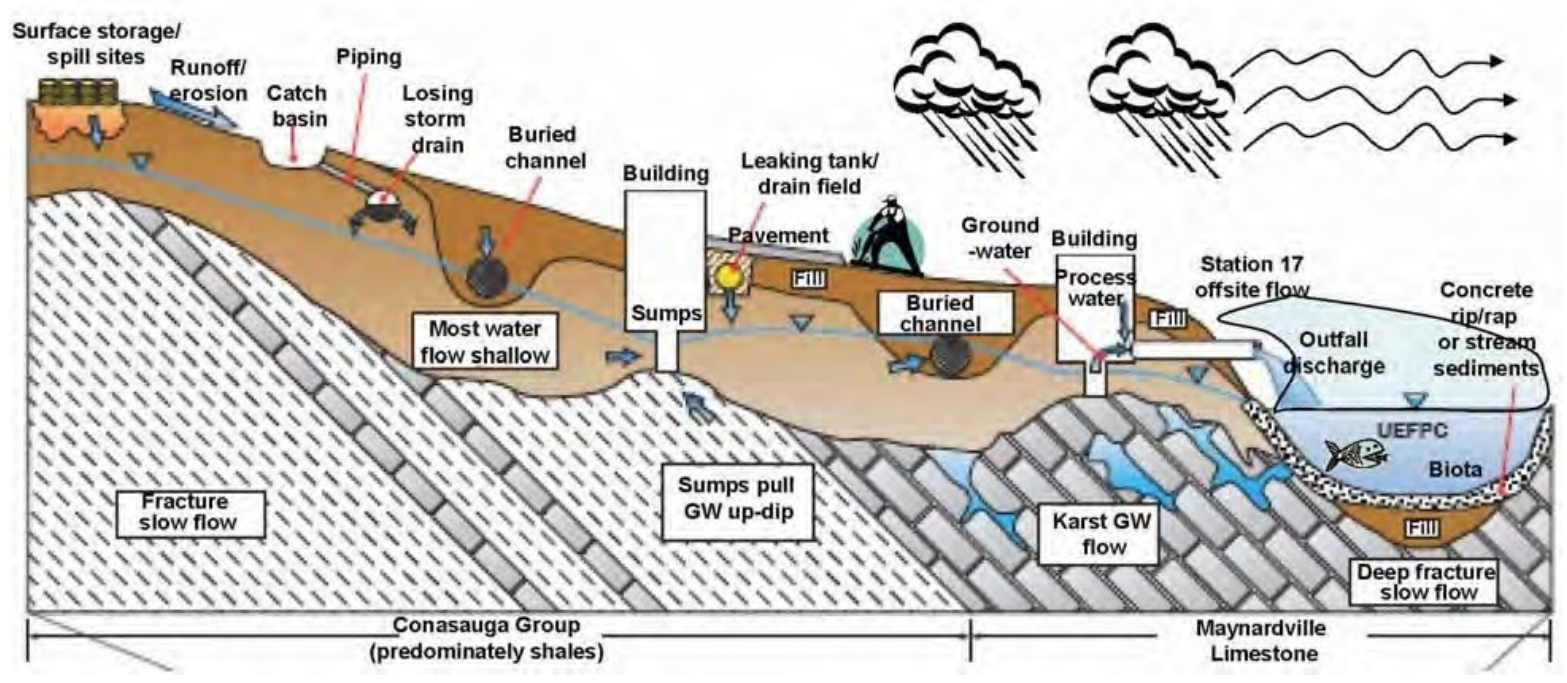

Figure 6. Major physical features affecting $\mathrm{Hg}$ processes and transport at Y-12 (based on Peterson et al. 2011). 


\section{REVISITING THE 2011 CONCEPTUAL MODEL}

The following are key conclusions from the 2011 conceptual model report:

- Of the known $\mathrm{Hg}$ inputs into UEFPC, OF200 was by far the most important source of $\mathrm{Hg}$ to creek water. Depending on flow conditions, OF 200 represented approximately $70 \%-80 \%$ of the flux observed at Station 17.

- Baseflow Hg flux from some WEMA outfalls (especially OF163) and OF200 appears to have increased from pre-Record of Decision levels in 2000. However, flux is highly variable and weather/flow-dependent, and higher fluxes have been observed before and after the 2000 assessment.

- Flux from OF150, OF160, OF163, and OF169 likely accounted for most, if not all, of the flux at OF200. Sediments within the north/south (N/S) pipe have not been sampled for $\mathrm{Hg}$ but are unlikely to be a major source.

- Under baseflow conditions, stream sediment provides the second most important continuing source of $\mathrm{Hg}$ into creek water upstream of OF109. Flow management appears to have increased flux from this sediment source.

- $\quad$ Big Springs Water Treatment System (BSWTS) successfully removed approximately $2-3 \mathrm{~g} / \mathrm{d}$ of $\mathrm{Hg}$ that entered UEFPC prior to BSWTS startup, as well as substantially reduced the average $\mathrm{Hg}$ concentration in the creek.

- Little direct evidence is available to establish that high $\mathrm{Hg}$ soil areas at 81-10 and Alpha 2, or low Hg sites at the far west end of the facility in or around the Old Salvage Yard, are sources of $\mathrm{Hg}$ to the creek.

Comparisons with past $\mathrm{Hg}$ conceptual models and $\mathrm{Hg}$ dynamics are useful in understanding how conditions and assumptions have changed over time. An updated version of the conceptual model diagram developed by Peterson et al. (2011), which represents an average flux during both baseflow and stormflow conditions, is shown in Figure 7. Fluxes where new data exist are highlighted. Figure 7 consolidates knowledge about $\mathrm{Hg}$ sources at $\mathrm{Y}-12$ and provides summary information on the transport of $\mathrm{Hg}$ through the system, including the approximate magnitude of flux. In this conceptual model, the bulk of the $\mathrm{Hg}$ mass is present in a variety of potential primary source locations. Over time, $\mathrm{Hg}$ is released from these primary sources via physical (e.g., diffusion and advection) or chemical (e.g., oxidation and complexation) processes. This $\mathrm{Hg}$ can enter one of the transport pathways (which may also contain metallic $\mathrm{Hg}$ acting as a primary source) and is subject to migration and potential discharge to the surrounding environment and potential on-site and off-site receptors. The primary sources each represent a "reservoir" of elemental $\mathrm{Hg}(\mathrm{Hg}(0))$ and/or particle-bound $\mathrm{Hg}$ and have historical linkages to a known release. Such primary source areas include the storm drain system, the solution cavity (karst) system, streambed sediments, buildings, sumps, footers, process pipes, tanks, and Hg nonaqueous-phase liquid collection zones in the subsurface. Some of these reservoirs are at or near the original release locations and some are distributed along transport paths (e.g., metallic $\mathrm{Hg}$ in solution cavities and storm drains). Figure 7 also provides basic information about the spatial connection of the identified sources and transport pathways (including building and outfall designations). 


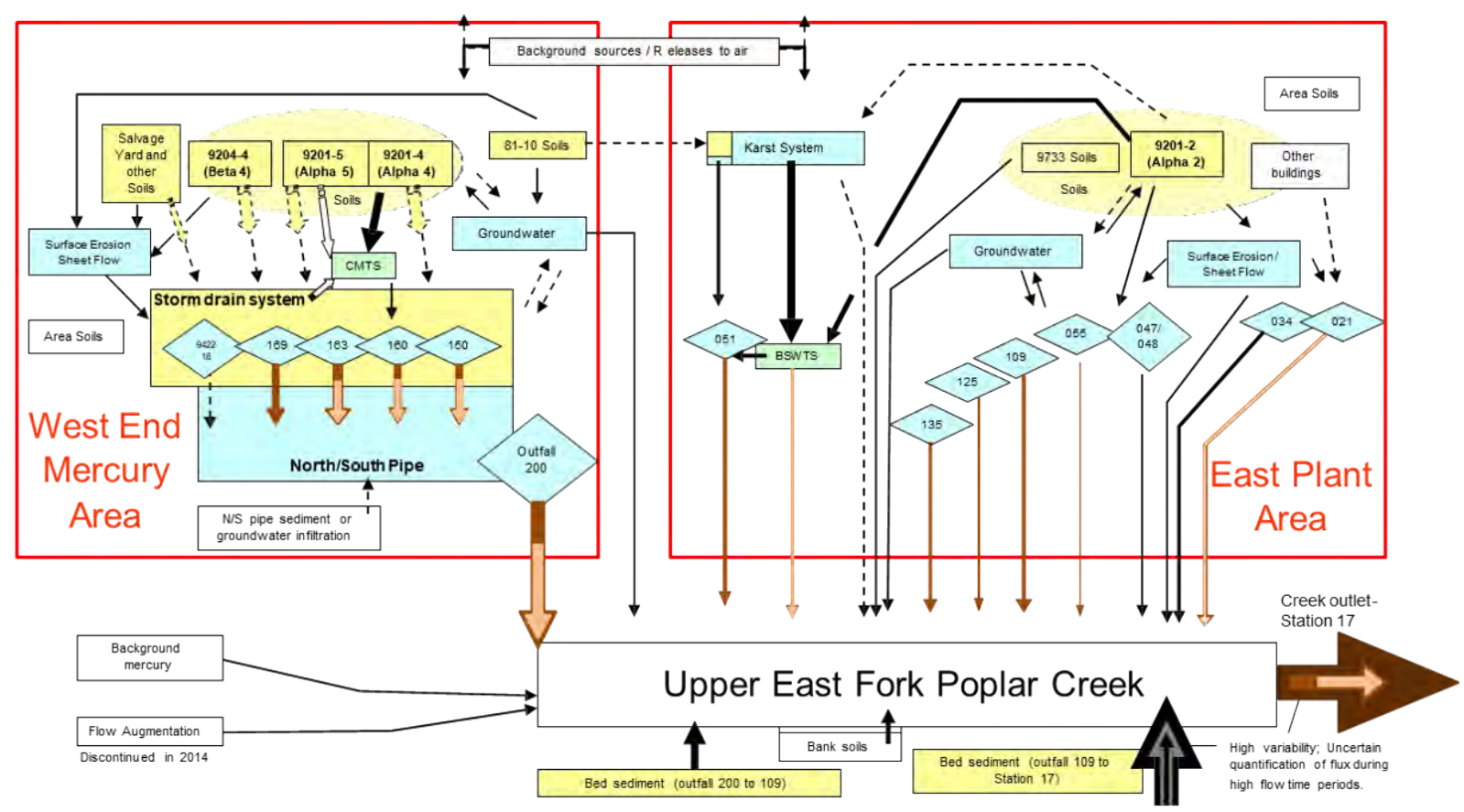

\begin{tabular}{|l|l|l|}
\hline Y-12 Mercury Conceptual Model Update & Legend \\
Title: Conceptual model for mercury showing \\
primary source areas, transport pathways, and \\
flux (grams/day) at the Y-12 Complex. Fluxes \\
with new data shown in brown. Fluxes where \\
no new data exist were retained from 2011 \\
diagram.
\end{tabular}

Figure 7. Updated conceptual model diagram from Peterson et al. (2011). 


\section{CONCEPTUAL MODEL REFINEMENTS}

The goal of this conceptual model update report is to analyze, summarize, and interpret $\mathrm{Hg}$ and methylmercury (MeHg) concentration and flux data collected since the 2011 conceptual model report. This update incorporates new data from multiple projects and funding sources, including the Mercury Technology Development project and the Oak Ridge National Laboratory Mercury Science Focus Area. Much of the flow and concentration data was downloaded from the Oak Ridge Environmental Information System. The primary objectives of this update are to improve upon the previous model by implementing a more detailed spatial and temporal approach to visualize transport pathways in the watershed and trends in flux and concentration over time, and to compare baseflow and stormflow system dynamics. The delineations and visualizations of the outfall drainage areas shown in Figures 1-3 add critical context to Hg dynamics in the UEFPC watershed and are an important component of this conceptual model update report. This update provides an interpretation of current conditions and should not be confused with output from a numerical modeling effort. A comprehensive, concurrent sampling of storm drains and transport pathways throughout Y-12 and UEFPC does not exist. Therefore, the analysis and interpretation of recent data presented herein uses sampling results from different years, often collected and analyzed using different methods and sampled during varied flow regimes.

An examination of total $\mathrm{Hg}$ concentrations from 2009 through 2018 (Figure 8) shows the highest concentrations in surface water across the UEFPC watershed continued to be in WEMA outfalls, especially OF163 and OF160. The Central Mercury Treatment System (CMTS) and BSWTS effluent

discharges had the lowest overall concentrations. An increase in concentrations was observed throughout and downstream of the WEMA in 2011 in response to a storm drain cleanout, which is consistent with previous spikes following storm drain cleanouts. 2011 was also the year with the highest rainfall. The other noteworthy spike in concentrations occurred in July 2018, which appears to be the result of a onetime influx of $\mathrm{Hg}$ that occurred during a D\&D event at Y-12. As mentioned previously, stream sediment between $\mathrm{C} 11$ and OF109 was thought to provide the second most important continuing source of $\mathrm{Hg}$ from the east end of Y-12 (the East Plant Area) into creek water during baseflow conditions. Flow augmentation was thought to have increased flux from this sediment source, but more data are needed to assess the impact of discontinuing flow augmentation on flux as no clear trend has been observed since it was discontinued. A noticeable increase in $\mathrm{Hg}$ concentrations occurred at instream monitoring point UEFPC at OF125 immediately after flow augmentation was stopped. UEFPC at OF125 is the monitoring point with the most complete data record between 2009 and 2018 that lies in between the flow augmentation creek input and OF109. 


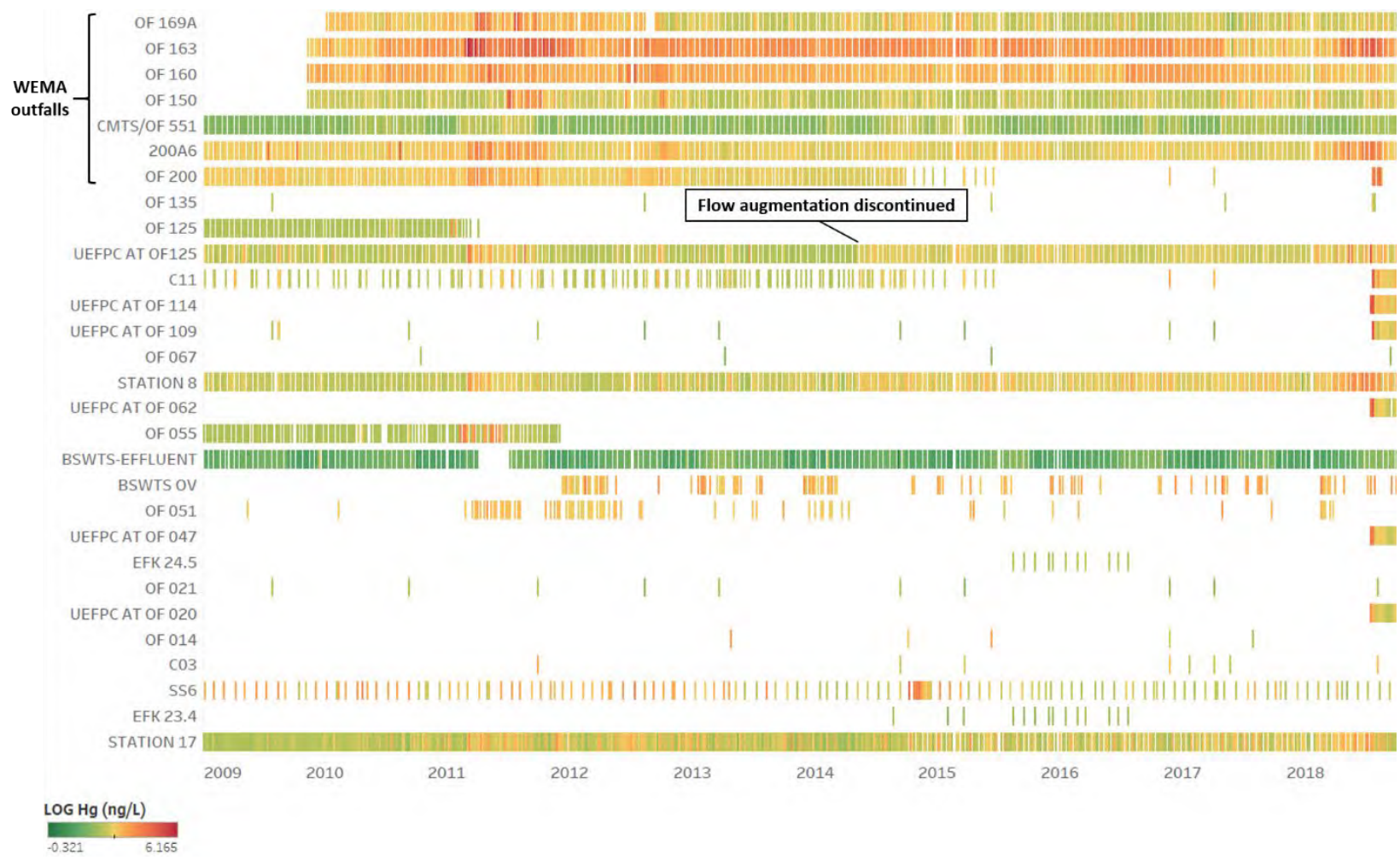

Figure 8. Total Hg concentrations over time at key monitoring locations. Concentrations log transformed for visualization purposes. Sampling locations sorted from upstream to downstream.

Because $\mathrm{Hg}$ flux can vary considerably depending on flow, interpretation of instantaneous results (e.g., grab samples) under various flow regimes over space and time can be difficult. For many of the storm drain sites, grab sample data were the only information available. Most previous sampling has been done at dry-weather baseflow, with less understanding of stormflow flux. Calculations of flow under wetweather conditions can be challenging, particularly in storm drains with poor access. An attempt was made to compare baseflow flux with stormflow flux using a daily rainfall total threshold of $0.5 \mathrm{in}$. to distinguish the two conditions. Some of the samples used to calculate stormflow flux could have been collected before that day's rainfall event. Since thousands of samples were collected over the 10-year period included in this model update effort, no attempt was made to compare timing of sample collection and rain events. Nevertheless, we wanted to visualize and interpret stormflow fluxes, so we elected to calculate baseflow and stormflow fluxes separately.

The variability in estimated $\mathrm{Hg}$ flux over time, location, and flow conditions is well demonstrated by the results presented in Figures 9-11. The largest flux during both baseflow and stormflow conditions occurred at OF163 in 2011 following the storm drain cleanout (Figure 9). Leading up to the storm drain cleanout, annual baseflow flux was higher at OF200A6 than at Station 17. Following the storm drain cleanout, this trend reversed until 2018. Annual stormflow flux was always higher at Station 17 than at OF200A6, with OF200A6 contributing on average $61 \%$ of the storm flux calculated at Station 17 from 2009 to 2018. 
(A) Baseflow (daily rainfall $<0.5$ inches)

(B) Stormflow (daily rainfall $>=0.5$ inches)

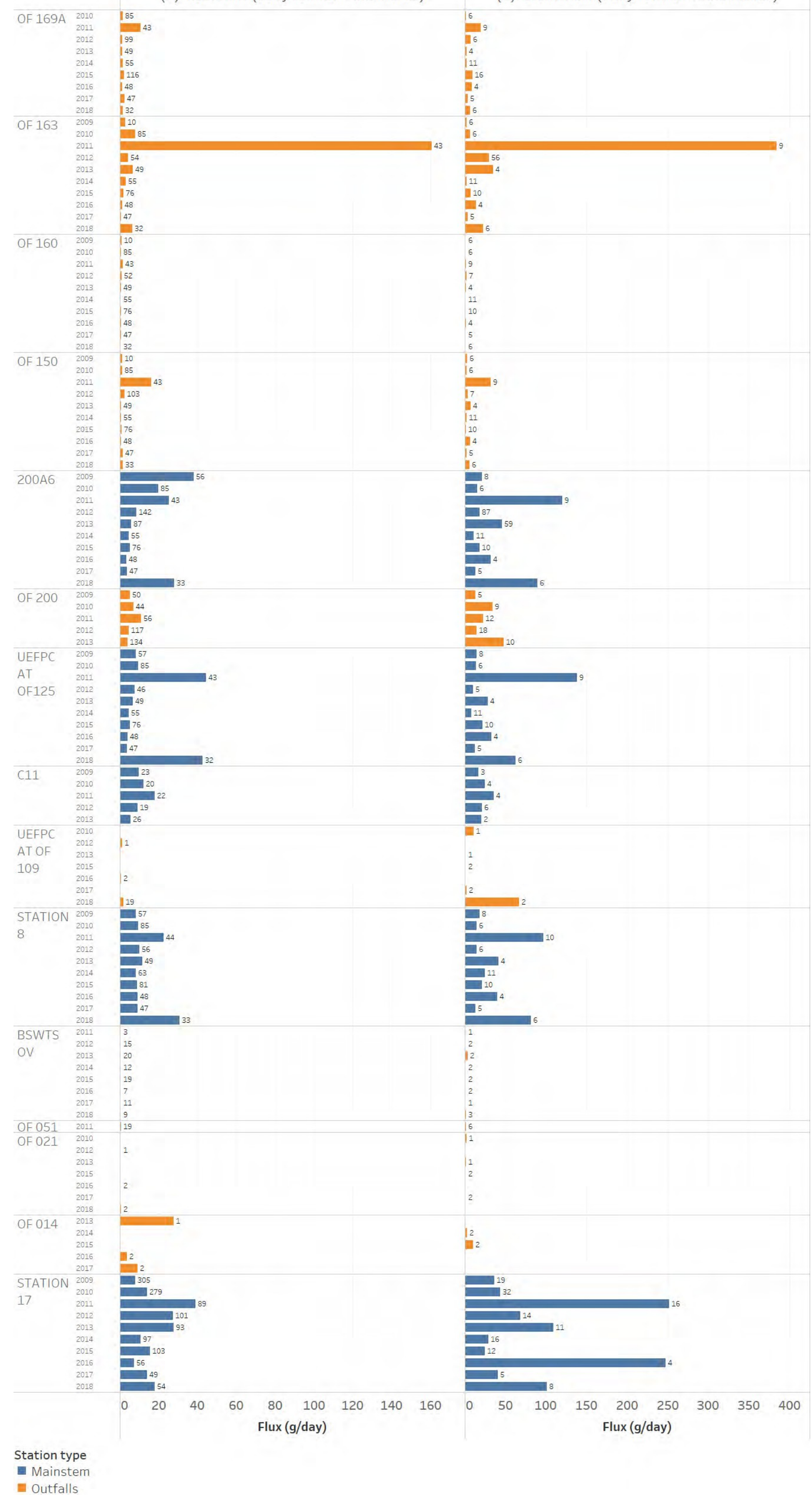

Figure 9. Annual Hg flux over time at key monitoring locations. (A) Baseflow and (B) stormflow. Labels show count of data values used in calculation. 
Both fluxes and concentrations of total $\mathrm{Hg}$ are important to achieving long-term remediation goals at Y-12. Prioritizing areas to target for remediation based on flux is practical in the near term, but regulatory agencies are also concerned with concentration. Thus, outfalls with low flow or low flux will become more important over time as major fluxes are reduced. For example, current efforts to reduce flux may concentrate in OF163 and once that source is eliminated, resources could then be focused on OF169A and OF150 (Figure 10). The cumulative effect should be substantial decreases in Hg flux from OF200A6 and OF200, permitting resources be devoted to in-stream sources in the reach between C11 and OF109.

Figure 11 shows average concentrations for outfall and EFPC mainstem sampling locations from 2009 to 2018 for baseflow and stormflow. The highest concentrations were detected at WEMA outfalls, but significant concentrations were detected in numerous East Plant Area outfalls, which will become more important after MTF becomes operable decreasing $\mathrm{Hg}$ concentration and flux originating from OF200.
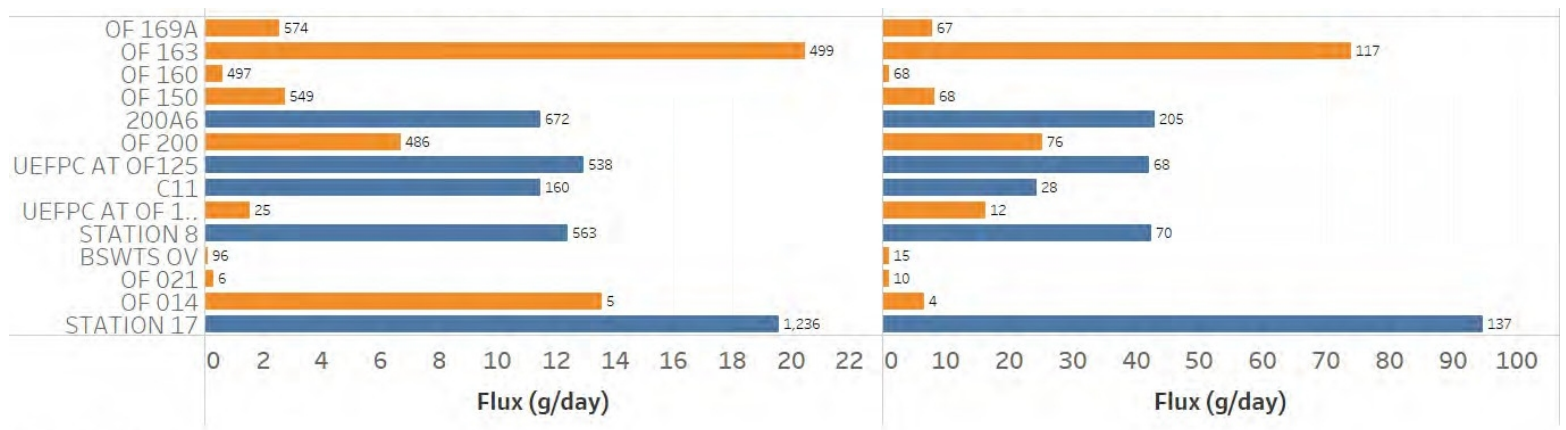

Station type

Mainstem

- Outfalls

Figure 10. Average total Hg flux from 2009 to 2018 at key monitoring locations. (A) Baseflow and (B) stormflow. Labels show count of data values used in calculation.

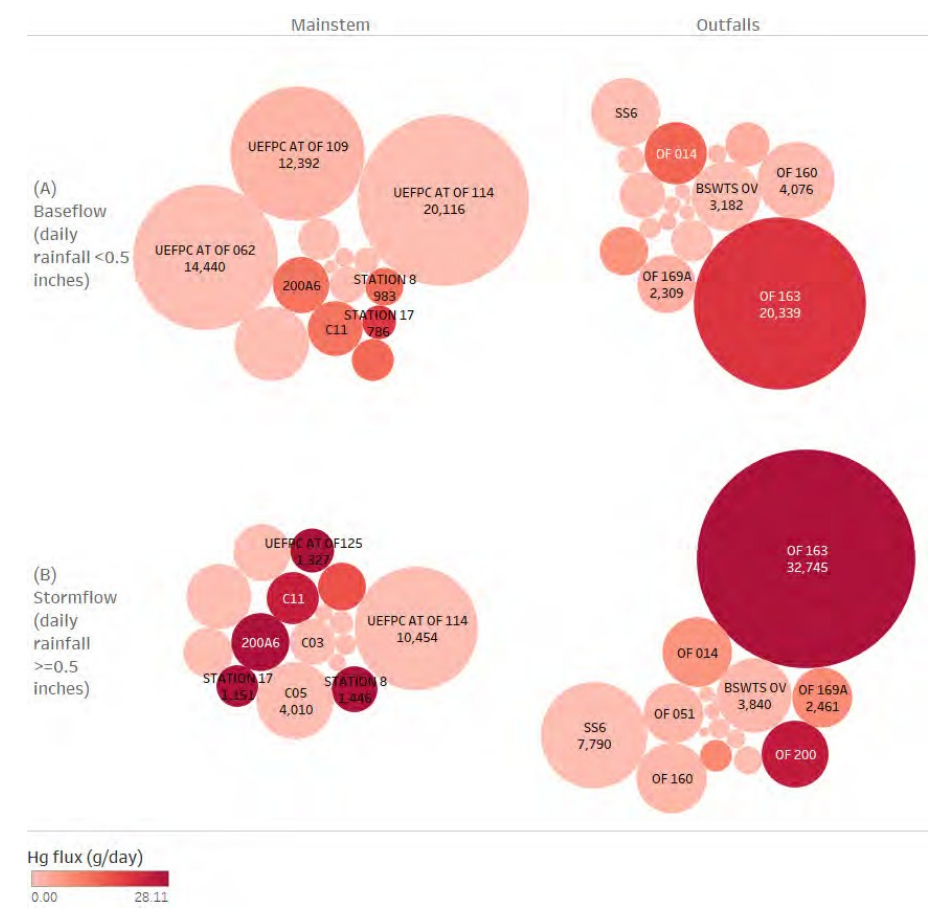

Figure 11. Mercury concentrations for mainstem and outfalls during baseflow and stormflow conditions. Bubble size indicates average $\mathrm{Hg}$ concentrations (ng/L) for 2009 to 2018. Labels on bubbles show sample location name and average concentration; bubble color shows average flux for 2009 to 2018. 
While much less MeHg data have been collected over the several decades of environmental assessment and remediation activities at $\mathrm{Y}-12, \mathrm{MeHg}$ has emerged as an important indicator in recent years since it is absorbed into the body of fish much more easily than inorganic $\mathrm{Hg}(\mathrm{Hg}(\mathrm{II})$ ), and $\mathrm{Hg}$ concentrations in fish have not decreased in conjunction with waterborne $\mathrm{Hg}$ reductions. The highest $\mathrm{MeHg}$ concentrations in recent years have been detected at WEMA outfalls OF163 and OF169 in 2012 and at mainstem monitoring location EFK 24.4 in 2017 (Figure 12). The highest MeHg fluxes appear to have occurred at Station 17 and EFK 24.4 (Figure 13), but limited data are available and further assessment is needed to discern trends in $\mathrm{MeHg}$ concentration and flux.

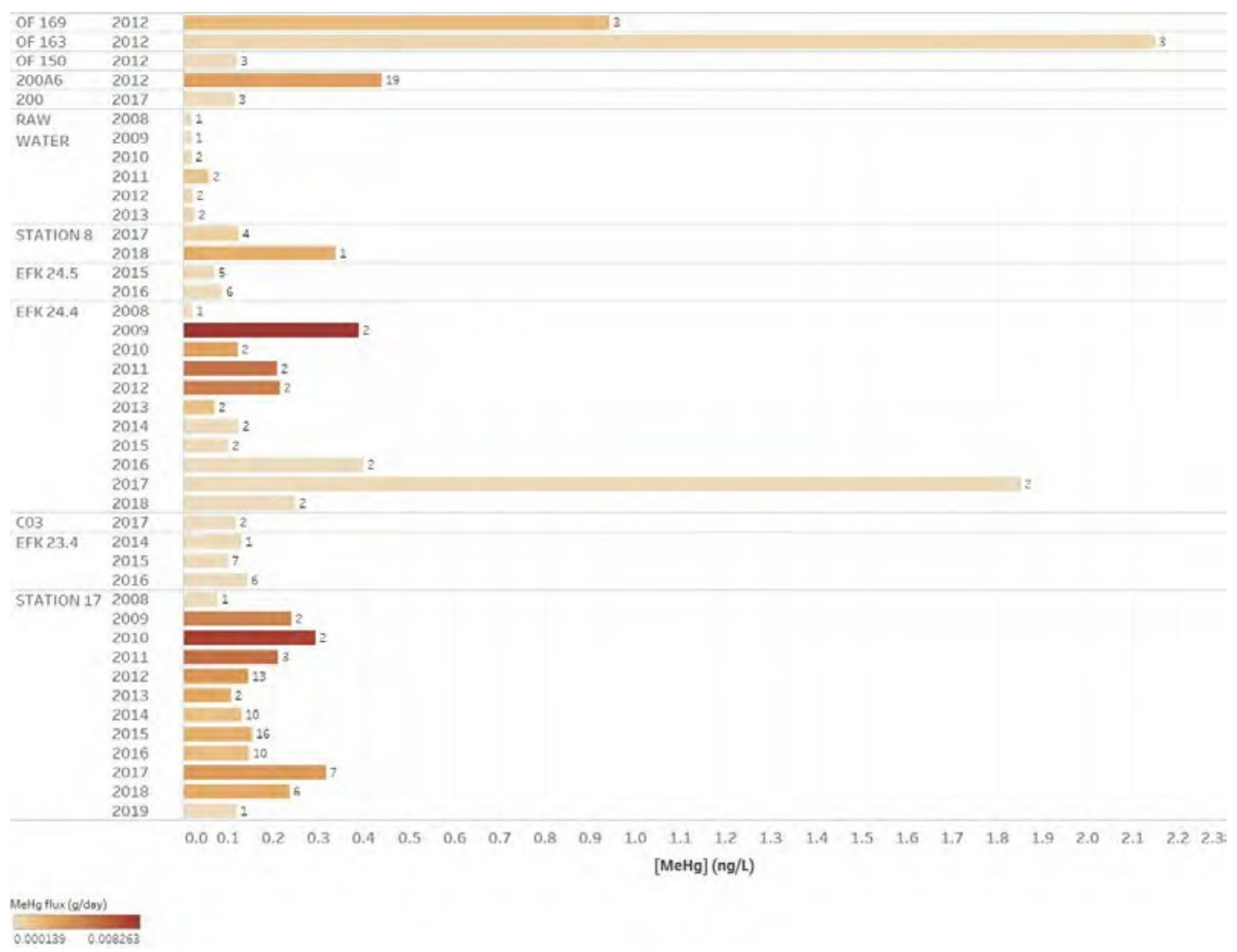

Figure 12. Methylmercury concentration over time at key monitoring locations. Labels show count of data values used in calculation. Color is proportional to MeHg flux (see figure legend). 


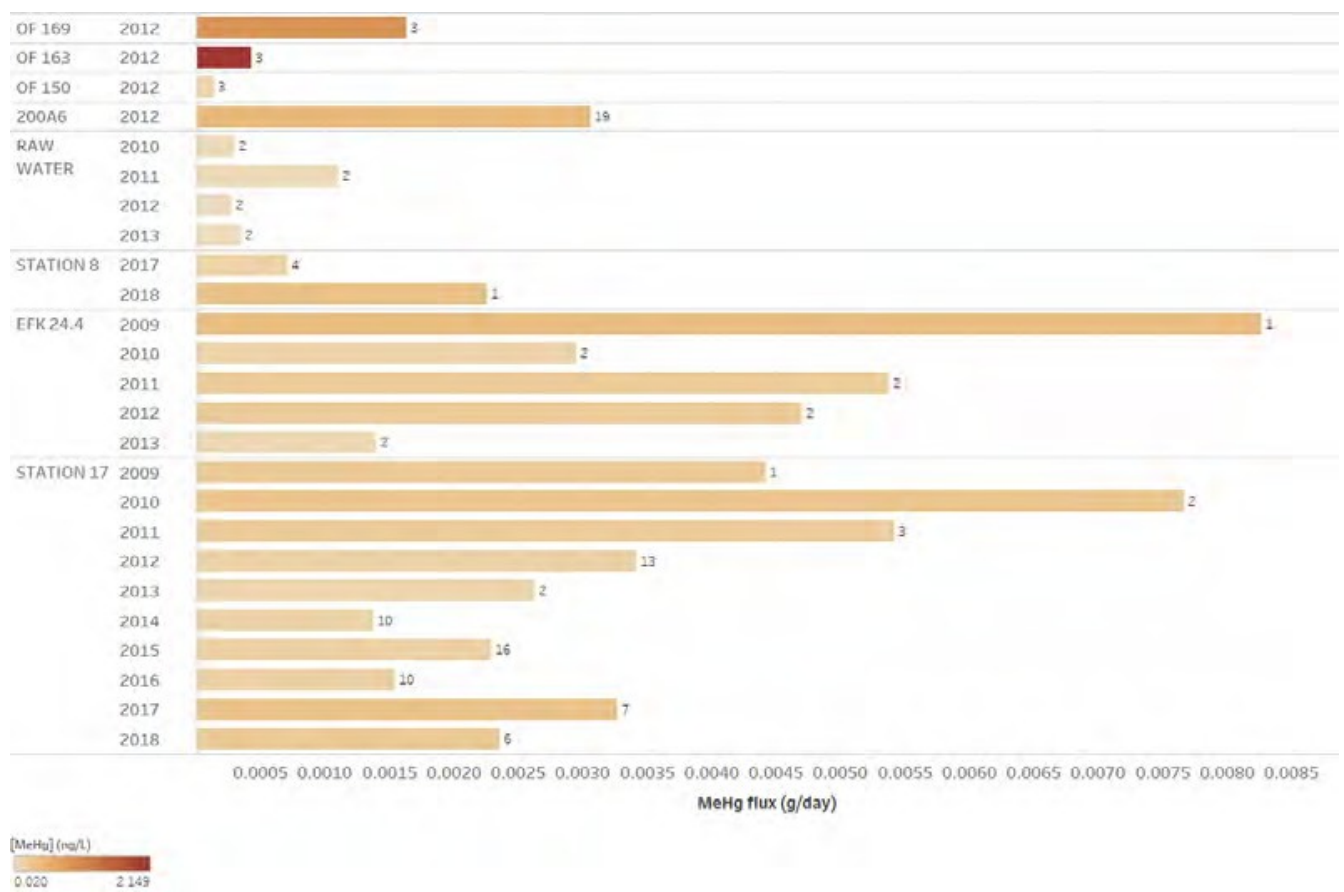

Figure 13. Methylmercury flux over time at key monitoring locations. Labels show count of data values used in calculation. Color is proportional to MeHg concentration (see figure legend). 


\section{MERCURY SOURCES AND TRANSPORT PATHWAYS}

For context, detailed descriptions of the principal Hg source areas, contaminant migration pathways, and discharge points for WEMA and the East Plant Area are provided in this section. The relative importance of source areas has changed over time as various facility modernization, D\&D, and remedial efforts have been implemented. Additional changes are expected in the future, including the construction of MTF, which will capture Hg-contaminated water from OF200 for treatment.

\subsection{WEST END MERCURY AREA}

In general, WEMA is defined as the area of Y-12 west of OF200 and east of the Old Salvage Yard (Figure 2). It comprises several large buildings that housed $\mathrm{Hg}$ use processes, with surrounding contaminated soils most often under overlying concrete or asphalt pavement. A storm drain system connecting pipes of different ages transports water from buildings and other impervious areas to OF200, where the creek exits the storm drain system.

\subsubsection{WEMA Buildings}

Facilities in WEMA (Figure 2) that handled Hg include Buildings 9204-4 (Beta 4), 9201-5 (Alpha 5), and 9201-4 (Alpha 4). These facilities now contain contaminated process equipment, legacy material, and portions of facility structures that are contaminated. A large percentage of the known 193,000 kg of $\mathrm{Hg}$ lost to soil at Y-12 was the result of historical spills (in the 1950s to 1960s) in WEMA (ChemRisk 1999). Significant but unknown quantities of metallic $\mathrm{Hg}$ were spilled to floor drains and basements in the buildings and on soils, engineered backfill, and bedrock surrounding the buildings. The lower portions of building foundations, basements, and surrounding fill, soil, and bedrock that are below the regional groundwater table are also contaminated with $\mathrm{Hg}$.

The piping systems inside the buildings contain residual $\mathrm{Hg}$ that was spilled into the floor drains or discharged from building sumps. Metallic $\mathrm{Hg}$ in the pipes is dissolved and transported into process and storm water that is routed through the pipes to the storm drain system. Evidence suggests continued migration of metallic $\mathrm{Hg}$ from the piping associated with the buildings to the storm drain system, but there is a high level of uncertainty as to its relative magnitude.

Groundwater adjacent to and under the buildings is collected into sump-pump systems. Sump pumps within the basements of 9201-4 and 9201-5 discharged directly to the storm drain network until 1996, when CMTS was completed. The sumps added 5-10 g of $\mathrm{Hg}$ per day to OF163, but output was reduced to $2.5 \mathrm{~g} / \mathrm{d}$ by the removal of inputs of chlorinated process water and steam condensate to the system (BJC 1999). Sump operation induces groundwater flow through metallic $\mathrm{Hg}$-contaminated soil around building foundations. These actions may generate highly contaminated water similar to that expected to occur within sediments and footers underlying the storm drain system. A methanol spill in a sump in 9201-5 in December 2005 rendered the output from sumps in that building untreatable at CMTS, and subsequently, all pumps in 9201-5 were shut down and the basement was allowed to fill with water.

Remedial activities to address flux from residual contamination within the buildings as part of the Reduction of Mercury in Plant Effluent Program and other programs have included plugging floor drains, rerouting some piping, cleaning out sumps, and generally reducing the amount of water moving through the building and into storm drains (Rothschild et al. 1984, Turner et al. 1985). These activities have significantly reduced the flux of $\mathrm{Hg}$ discharging to the storm drain system, although much of the $\mathrm{Hg}$ remains in place. 


\subsubsection{WEMA Storm Drain System}

Sources of $\mathrm{Hg}$ to EFPC were extensively investigated in the early 1980 s to guide efforts to reduce $\mathrm{Hg}$ inputs to EFPC under the Reduction of Mercury in Plant Effluent Program (RMPE; Rothschild et al. 1984, Turner et al. 1985). One conclusion of these studies was that "mercury discharges arise largely because residual deposits of metallic mercury in the drainage system are being slowly solubilized or resuspended by uncontaminated groundwater and process water which flows through the system" (Turner et al. 1985). Another important conclusion was that "mercury [in groundwater] does not appear to be moving in significant quantities in an aqueous phase" (Rothschild et al. 1984). Measurements of base flow $\mathrm{Hg}$ export indicated that the largest sources were the storm drain systems draining Buildings 9204-4 $(55 \mathrm{~g} / \mathrm{d}), 9201-5(40 \mathrm{~g} / \mathrm{d})$, and 9201-4 $(25 \mathrm{~g} / \mathrm{d})$, and the Building 81-10 site $(30 \mathrm{~g} / \mathrm{d})$. Cleaning and relining extensive sections of the storm drain systems draining the 9201-4, 9201-5, and 9204-4 sites and rerouting clean water that previously entered those storm drain segments eliminated more than $90 \%$ of the $\mathrm{Hg}$ export previously associated with those sites. These actions resulted in a cumulative mean daily flux of $7.5 \mathrm{~g} / \mathrm{d}$ through OF169, OF163, OF160, and OF150 from 1993 to 2003 (DOE 2004). The 2009 WEMA storm drain project and 2011 storm drain cleanout conducted extensive video surveys, $\mathrm{Hg}$ analyses, and additional cleaning/relining of storm drain lines within WEMA. As in other surveys, the results pointed to the importance of the 9201-4 area and near-building storm drain sources to OF163 and OF150.

The north storm drain line into the E-3320 catch basin (i.e., E-3250 in RMPE reports) was a major source of $\mathrm{Hg}(2-3 \mathrm{~g} / \mathrm{d})$ to OF169 in the 1990s. A collection line inserted into the north drain line of E-3320 in 1998 captured much of the dry-weather flow from this line and routed it to CMTS (BJC 1999, BJC 2000). After the discontinuation of routing this water to CMTS, the flow pattern just upstream of this catch basin changed. Although WEMA storm drain remediation sampling did not identify $\mathrm{Hg}$ flux at the OF169 location near the E3320 catch basin, 2010 sampling at E-3249 (just north of E-3320) revealed total Hg of $25 \mu \mathrm{g} / \mathrm{L}$ and sufficient flow to collect a large volume of water. Although OF163 appears to be a more important contributor than OF169 to OF200 Hg flux in recent years, OF 169 likely remains an important contributor of $\mathrm{Hg}$ to overall WEMA flux. In 2015, the OF169 sampling location was replaced by OF169A, located approximately $120 \mathrm{ft}$ downstream in the storm drainpipe.

In the late 1980s, the main storm drain conveyance for EFPC - into which the WEMA outfalls discharge - was plugged and replaced with a new pipe located several meters to the north. The south pipe was removed as a source of $\mathrm{Hg}$ to UEFPC, resulting in elimination of approximately $30 \mathrm{~g} / \mathrm{d}$ of $\mathrm{Hg}$ to the EFPC headwaters. By the early 1990s, metallic Hg sources within the WEMA storm drain system were considered the major source of dissolved $\mathrm{Hg}$ to west end surface waters.

Metallic $\mathrm{Hg}$ submerged in water is subject to direct dissolution of elemental mercury $(\operatorname{Hg}(0))$ and oxidative dissolution of inorganic mercury $(\mathrm{Hg}(\mathrm{II}))$ at the metal-water interface. Mercury concentrations in excess of $50 \mu \mathrm{g} / \mathrm{L}$ have been measured in interstitial water at a localized site in UEFPC, where metallic $\mathrm{Hg}$ deposits underlie armored soft sediments. This site is believed to be a significant source of $\mathrm{Hg}$ to the surface flow of EFPC (BJC 1998). We are nearly certain that a similar phenomenon occurs within the storm drain network upstream; residual $\mathrm{Hg}$ in the footer, backfill, and gravel deposits within the pipe is a likely source to water. Positive hydrostatic pressure from groundwater could force highly contaminated water surrounding pipes into the drainage system via joints and cracks in non-remediated sections, while flow within the footer/backfill could enter the creek at points downstream.

\subsubsection{WEMA Soils and Groundwater}

A 1980s investigation of subsurface $\mathrm{Hg}$ at $\mathrm{Y}-12$ found high concentrations of $\mathrm{Hg}$ in shallow $(<10 \mathrm{ft})$ soil near Buildings 9201-2, 9201-4, 9201-5, 9204-4, and 81-10 but little evidence of deeper movement at most sites (Rothschild et al. 1984). Uncertainty exists as to whether metallic Hg in soil near WEMA buildings 
is a significant source to the storm drain system, but some degree of intrusion is highly likely. Alternatively, intra-building sources, including blocked floor drains, may be the most likely sources to downstream storm drain lines. Broken or severely damaged conduits are necessary for soil $\mathrm{Hg}$ to enter sewers. Mercury entering damaged storm drains is most likely from surrounding footers or fill material and not from the surrounding native soils. Although some evidence of cracked and broken pipe exists, the 2009 WEMA storm drain project did not observe large sections of sewer with catastrophic damage. However, very small pipes near buildings were not surveyed as effectively as larger sewer lines.

Groundwater connectivity among soil contamination, storm drains, shallow (soil-zone) groundwater, construction-filled stream channels, and karst and nonkarst bedrock flow paths is important but not well understood. Based on limited available information, groundwater within WEMA does not show strong evidence of $\mathrm{Hg}$ mobilization from soil, with groundwater concentrations in wells at most contaminated sites being lower than concentrations in storm drains and stream surface flow. Previous studies have detected and delineated groundwater plumes of nitrate, sulfate, chloride, conductance, and alkalinity, but little evidence exists of a significant plume of $\mathrm{Hg}$-contaminated groundwater, although $\mathrm{Hg}$ has been detected in groundwater wells (Rothschild et al. 1984, DOE 1998).

\subsubsection{The 81-10 Site as a Source}

Mercury contamination at the 81-10 site, situated above the Maynardville Limestone bedrock, extends deeper than at sites situated above shale bedrock (Rothschild et al. 1984). This site was the location of a $\mathrm{Hg}$ distillation/recycling system (i.e., a retort) and stored drums of $\mathrm{Hg}$ sludge. Metallic $\mathrm{Hg}$ that was spilled on the concrete pad at 81-10 leaked into a sump that overflowed to the main storm drain (N/S pipe) conveying water to EFPC (Turner et al. 1985). The 81-10 site is underlain by limestone that has karst development. Metallic Hg spilled on-site may have penetrated into the karst system (Moline et al. 1998, Moline et al. 2001, DOE 2001). Also, the original creek channel adjacent to the 81-10 site (now covered by the N/S pipe) could have been a losing reach that discharged water into the karst system. This is similar to what is currently observed in Bear Creek, which is in the same geologic formation as UEFPC. Metallic Hg in the footer underlying the original N/S pipe could thus act as a source to the karst system. Dissolved $\mathrm{Hg}(0)$ and $\mathrm{Hg}(\mathrm{II})$ were detected in a piezometer that may have encountered a solution cavity more than $100 \mathrm{~m}$ downstream of OF200. Moline et al. (2001) suggested that a connection exists to the Big Springs (karstic groundwater) discharge (OF51) adjacent to 9201-2 located $800 \mathrm{~m}$ downstream. Overall, the data obtained to date suggest that some of the Hg-contaminated groundwater entering BSWTS may originate from the 81-10 site and spills near 9201-2.

Soil and sediment cores were collected in 2010 at the 81-10 site to address characterization data gaps that had been identified after previous studies and as a substitute for treatability studies called for in the Record of Decision (DOE 2002; ORISE 2010). Mercury contamination was found in cores taken adjacent to the remnant concrete slab of the former facility and, when present, tended to be localized to the upper $10 \mathrm{ft}$ of soil. Soils surrounding the former 9822 Sediment Basin produced relatively low $\mathrm{Hg}$ concentrations $(<1 \mathrm{mg} / \mathrm{kg})$, indicating that the basin is probably not a source of contamination to the creek. Along the northern edge of the slab of the former retort furnace, however, high concentrations $(>300 \mathrm{mg} / \mathrm{kg}$ ) were observed at moderate depths (14-30 ft), which are significantly above the level of the basement rock. Visible $\mathrm{Hg}$ beads and droplets were observed in two of the cores collected during this study, and $\mathrm{Hg}$ concentration up to $1,400 \mathrm{mg} / \mathrm{kg}$ was measured in a third. Mercury-contaminated soil with concentrations greater than $325 \mathrm{mg} / \mathrm{kg}$ covers an estimated surface area of approximately $8,080 \mathrm{ft}^{2}$.

As part of EM-32-funded projects, ORNL and Savannah River National Laboratory staff conducted additional investigations of the 81- 10 site in 2010. ORNL staff conducted a detailed interrogation of two cores showing that metallic $\mathrm{Hg}$ was associated with coarser, more gravelly zones, especially those on top of low-permeability clayey zones (perhaps a historical surface grade) where the $\mathrm{Hg}$ pooled on top of the 
clay. These coarser-grained zones likely provide avenues for transport and downward migration of the $\mathrm{Hg}$ beads.

Overall, there is clear evidence of significant $\mathrm{Hg}$ concentrations in soils near the 81-10 retort furnace, but many questions must be answered before determining to what degree, if at all, the former 81-10 site serves as a source of $\mathrm{Hg}$ to EFPC. If the conclusions of the 1980s studies are still valid and $\mathrm{Hg}$ from 81-10 moves through subsurface conduits to the Big Springs area, then 81-10 Hg is likely being treated by BSWTS and is not a major current source of $\mathrm{Hg}$ to the creek. However, this may only be true to the extent OF-51 is not a major source of $\mathrm{Hg}$ to the creek.

Considerable $\mathrm{Hg}$ concentrations were detected at $\mathrm{OF}-51$, but it is unknown what proportion of that $\mathrm{Hg}$ load may originate from 81-10.

\subsubsection{WEMA Surface Soil Erosion and Wet-Weather Export}

Studies of stormflow $\mathrm{Hg}$ transport in EFPC conducted in 1997 and 1998 clearly demonstrated that most of the increased $\mathrm{Hg}$ flux associated with rainfall events originated from erosion/resuspension of fine particulates from the open streambed downstream from OF200 rather than within the enclosed storm drain network above the outfall (Lockheed Martin Energy Systems, Inc. 1997, BJC 1998, 1999, 2000).

Mercury concentrations on particulates at OF200 during elevated flow were typically low ( $<20 \mathrm{mg} / \mathrm{kg})$, whereas concentrations at downstream sites were $50-100 \mathrm{mg} / \mathrm{kg}$. Similarly, storm flow-related $\mathrm{Hg}$ flux at a site 5,000 ft downstream was five times higher than at OF200. Although $\mathrm{Hg}$ flux at OF200 increased in response to increased discharge during wet weather, most of the increase was associated with greater flux of dissolved $\mathrm{Hg}$ rather than inputs of particle-associated $\mathrm{Hg}$ expected from erosion of contaminated surface soil. There was no indication that soil erosion from the Old Salvage Yard and other areas in the west end of Y-12 was an important source of $\mathrm{Hg}$ to the N/S pipe or EFPC.

Various conduits leading from buildings to the storm drain network, such as floor and roof drains, have the potential to contain residual deposits of metallic $\mathrm{Hg}$. Increased flow in such pathways during rainfall events can move metallic $\mathrm{Hg}$ downstream into the storm drain network or move metallic $\mathrm{Hg}$ already in the storm drain system farther downstream. Periodic appearance of metallic $\mathrm{Hg}$ in junction boxes within the storm drain network (and subsequent removal by Y-12 staff) gives evidence that such movement is occurring.

\subsection{EAST PLANT AREA}

The principal Hg source areas, contaminant migration pathways, and discharge points for the East Plant Area-defined here as the zone between OF200 (at the boundary of WEMA) and Station 17 near Scarboro Road - are shown on Figure 3. Within the Y-12 facility boundary, UEFPC is within the eastern part of the plant and receives a number of relatively low-concentration $\mathrm{Hg}$ inputs from storm drains, process water lines, groundwater (including karst-related inputs via OF51), sheet flow/erosion, and a treatment system discharge.

The East Plant Area appears to contribute a small percentage of the total flux to the creek compared with inputs from WEMA via OF200 into the creek's headwaters and contributions from the contaminated creek sediment. This low-level flux from the East Plant Area (outside of bank soils) assumes continued treatment of groundwater contamination in the area. A complicating factor is that east end sampling for $\mathrm{Hg}$ in storm drains, apart from OF51 and BSWTS-related sampling, has been less comprehensive than the sampling at WEMA. Most often, the available $\mathrm{Hg}$ data used in the conceptual model were from 
intermittent grabs during baseflow conditions, but several grab samples were collected between 2009 and 2018 at OF14, OF21, and OF109 on days with more than 0.5 in. of rainfall.

\subsubsection{East Plant Area Buildings}

The East Plant Area contains a number of buildings in which $\mathrm{Hg}$ was historically handled. Those buildings include 9201-2 (Alpha 2), 9733-1, 9202, and 9733-2. Mercury has been detected within and surrounding other buildings and soils in the east end but at much less significant levels. Alpha 2 represents a particularly difficult remediation challenge in the east end relative to $\mathrm{Hg}$, with major losses reported to surrounding soils, as well as major spills inside the building that seeped to the building's basement. Most of the building drain, sump, and groundwater issues identified for the WEMA buildings are applicable to Alpha 2. A sump in the basement of Alpha 2 extracts Hg-contaminated water that is pumped to BSWTS. The Hg in basement water is presumed to come from groundwater surrounding the building, legacy $\mathrm{Hg}$ from spills in the building itself, and abandoned piping still in the facility. Soils surrounding the 9733 area were partially remediated many years ago, but $\mathrm{Hg}(0)$ remains elevated. At all of the $\mathrm{Hg}$ use buildings without dewatering sumps, residual $\mathrm{Hg}$ contamination exists within soil and shallow groundwater beneath and adjacent to the buildings, but the extent to which this $\mathrm{Hg}$ finds its way to storm drain or surface flow paths to the creek in this area is still not well understood.

\subsubsection{East Plant Area Soil and Groundwater}

The east end of the facility is influenced by a primary source of groundwater flow that travels from west (within WEMA) to east. Soils and groundwater around the 81-10 site within WEMA contain high $\mathrm{Hg}$ concentrations. Mercury in groundwater may flow from the 81-10 area into the east end of the facility through preferential flow paths, including (1) karst conduits and fractures at intermediate and deep intervals in the Maynardville Limestone, (2) the old UEFPC stream channel, and (potentially) (3) shallow groundwater flow along pipes and porous fill areas.

The hydrogeologic system in the eastern area of Y-12 is complex since the various construction activities in the eastern plant area have affected groundwater and surface water flow patterns. Mercurycontaminated groundwater in this area is thought to be primarily captured by BSWTS. The amount of $\mathrm{Hg}$ removed by the treatment system has far exceeded that which previously entered EFPC via OF51, especially during the first few years of operation. OF51 has historically been the most contaminated outfall exiting the East Plant Area into the creek and represents the bulk of known Hg-contaminated groundwater still entering the creek. OF51 also receives BSWTS bypass flow that can be substantial during high precipitation events. OF51 water historically contained a strong dissolved $\mathrm{Hg}(0)$ signal, potentially linked to subsurface metallic $\mathrm{Hg}$ in the limestone solution cavity network (e.g., spills around 9201-2 or possibly from 81-10 or under N/S pipe).

Shallow groundwater in the East Plant Area is likely to be intercepted by storm drains, but the extent to which groundwater is a $\mathrm{Hg}$ source to specific storm drains is not well known. No known $\mathrm{Hg}$ contaminated large springs or extensive seepage areas enter UEFPC (aside from Big Springs via BSWTS and OF51) and, therefore, no known Hg groundwater sources directly enter the creek. If low-level inputs exist, they are too small to be observed from changes in $\mathrm{Hg}$ concentration in water. Karst system discharges flowing over spilled $\mathrm{Hg}(0)$ should have a strong $\mathrm{Hg}(0)$ component that would be readily detectable above the very low concentrations of dissolved gaseous $\mathrm{Hg}$ in UEFPC. However, the complex and rapid photooxidation chemistry of $\operatorname{Hg}(0)$ in water (half-life $\sim 1 \mathrm{~h}$ ) suggests that dedicated sampling efforts might be needed to identify the possible diffuse sources of $\mathrm{Hg}$ to the creek. Additionally, given the complexity of the subsurface environment in this area and the nature of karst geology, future construction activities have the potential to dramatically change subsurface flow paths, and future additional inputs to the creek are possible. 


\subsubsection{East Plant Area Storm Drain System}

As is the case in the WEMA, the East Plant Area storm drains themselves are sources of $\mathrm{Hg}$ to the creek, either by trapping $\mathrm{Hg}$ at the bottom of pipes and catch basins or via cracks in pipes that allow infiltration of contaminated groundwater. In the case of old and cracked storm drain lines, the pipe footer may be a sink or trap for $\mathrm{Hg}$ during baseflow conditions and a source of additional flux during rain events. The footers or spaces surrounding the storm drainpipe may be an additional, separate conduit for $\mathrm{Hg}$ contaminated water to the creek. Although in the east end of the facility individual storm drains contribute a small percentage of the total flux to the creek, a number of storm drains have detectable Hg inputs to the creek that may become more important sources to evaluate after MTF comes online and flux from OF200 is decreased.

\subsubsection{East Plant Area Ungauged Flux}

Ungauged sources can arise from (1) the infiltration of Hg-contaminated groundwater into the surface flow, (2) dissolution of $\mathrm{Hg}(\mathrm{II})$ and $\mathrm{Hg}(0)$ from within the streambed, and (3) desorption, dissolution, and/or resuspension of $\mathrm{Hg}$ from stream-bank soils that slough off into the creek. Although $\mathrm{Hg}$ is found at elevated concentrations in almost all earthen banks and sediment in UEFPC, the primary source of ungauged $\mathrm{Hg}$ flux to creek water during baseflow is a highly contaminated sediment zone upstream of OF109. Beads of $\mathrm{Hg}$ have been observed along with high concentrations of dissolved $\mathrm{Hg}$ within the gravel substrate. Past studies suggest that surface flow from flow augmentation enters the contaminated streambed to eventually reenter the surface flow at much higher $\mathrm{Hg}$ concentrations downstream (Southworth et al. 2009, 2010a).

Recent studies of wet-weather export of $\mathrm{Hg}$ from the EFPC watershed found that most $\mathrm{Hg}$ exported from the watershed under high flow originated from erosion of stream banks and streambed deposits downstream from Y-12 (Southworth et al. 2010b, Watson et al. 2016, Riscassi et al. 2016). Virtually all $\mathrm{Hg}$ exported under these conditions was particle-associated, but Riscassi et al. (2016) also found increasing dissolved $\mathrm{Hg}$ with increasing discharge (and turbidity). Although wet-weather flows appear to account for most of the total $\mathrm{Hg}$ export from the watershed, the continued baseflow input of dissolved $\mathrm{Hg}$ originating within Y-12 sustains the day-to-day exposure of aquatic life in the stream. 


\section{CONCLUSIONS AND RECOMMENDATIONS}

Based on the current conceptual understanding of $\mathrm{Hg}$ sources, transport, and flux at Y-12 and UEFPC, the following conclusions and recommendations should be considered during the environmental management decision-making process relative to $\mathrm{Hg}$.

\subsection{CURRENT CONDITIONS}

- Of the known $\mathrm{Hg}$ inputs into UEFPC, OF200 continues to be the most important current source of $\mathrm{Hg}$ to creek water. On average, including baseflow and stormflow conditions from 2009 to 2018, OF200 (measured at OF200A6) represents approximately $61 \%$ of the flux observed at Station 17 . This is a reduction from the $70 \%-80 \%$ reported in the previous conceptual model.

- The highest concentrations in surface water across the UEFPC watershed continue to be in WEMA outfalls, especially OF163 and OF160.

- An increase in concentrations occurred throughout and downstream of WEMA in 2011 in response to a storm drain cleanout.

- The largest flux during baseflow and stormflow conditions occurred at OF163 in 2011 following the storm drain cleanout. Leading up to the storm drain cleanout, annual baseflow flux was higher at OF200A6 than at Station 17. Following the storm drain cleanout, this trend reversed until 2018.

- A noticeable increase in $\mathrm{Hg}$ concentrations occurred at instream monitoring point UEFPC at OF125 immediately after flow augmentation was stopped. UEFPC at OF125 is the monitoring point with the most complete data record between 2009 and 2018 that lies in between the flow augmentation creek input and OF109.

- A noteworthy spike in concentrations occurred in July 2018, potentially due to a one-time influx of $\mathrm{Hg}$ that occurred during a D\&D event at Y-12.

\subsubsection{RECOMMENDATIONS}

- Further assessment is needed to understand the connections among periphyton, $\mathrm{MeHg}$ concentrations, bioavailability, and bioaccumulation. Because of the role of periphyton in $\mathrm{Hg}$ methylation and bioaccumulation, understanding the factors controlling periphyton growth and metabolic activity is crucial to understanding $\mathrm{Hg}$ transformation and bioaccumulation in stream systems.

- While under high flows much of the $\mathrm{Hg}$ has short residence time in the system (i.e., is transported downstream), these flows mobilize a lot of $\mathrm{Hg}$ and replenish $\mathrm{Hg}$ in sediments and porewater. Identifying and understanding these high flow transport pathways (that may be different than under baseflow) is a critical need.

- Transport pathway identification, delineation, and sampling is needed that includes measurement of $\mathrm{Hg}$ concentration and flow under baseflow and stormflow conditions concurrently at multiple sites.

- There is significant uncertainty associated with shallow groundwater movement near contaminated buildings and interactions with preferred flow paths and subsurface infrastructure. Further study is needed to understand interactions among storm drains, footers/backfill, and surrounding soil. Most wells at Y-12 were not designed to help understand these processes. 
- The conceptual model for Hg identifies the major sources and transport pathways for $\mathrm{Hg}$ at Y-12, but the many small sources of $\mathrm{Hg}$ identified in the model may also be important if the goal is to reach very low $\mathrm{Hg}$ levels in stream water and fish. Additional $\mathrm{Hg}$ flux information is needed for these sites, especially during high flow conditions.

- In the complex Hg environment of Y-12 and UEFPC, conceptual models should be regularly updated for effective environmental management decision-making. Comparisons with past $\mathrm{Hg}$ conceptual models and $\mathrm{Hg}$ dynamics are useful in understanding how conditions and assumptions have changed over time. 


\section{REFERENCES}

BJC (Bechtel Jacobs Company LLC). 1998. Mercury Abatement Report for the U.S. Department of Energy Oak Ridge Y-12 Plant for Fiscal Year 1998, Oak Ridge, Tennessee. BJC/OR-183.

BJC (Bechtel Jacobs Company LLC). 1999. Mercury Abatement Report for the U.S. Department of Energy Oak Ridge Y-12 Plant for Fiscal Year 1999, Oak Ridge, Tennessee. BJC/OR-422.

BJC (Bechtel Jacobs Company LLC). 2000. Mercury Abatement Report for the U.S. Department of Energy Oak Ridge Y-12 Plant for Fiscal Year 2000, Oak Ridge, Tennessee. BJC/OR-782.

Brooks, S. C. and G. R. Southworth. 2011. "History of mercury use and environmental contamination at the Oak Ridge Y-12 Plant." Environmental Pollution 159(1): 219-228.

doi:10.1016/j.envpol.2010.09.009

ChemRisk. 1999. Mercury Releases from Lithium Enrichment at the Oak Ridge Y-12 Plant-A Reconstruction of Historical Releases and Off-site Doses and Health Risks, Task 2 Report of the Oak Ridge Dose Reconstruction, Volume 2.

DOE (US Department of Energy). 1998. Report on the Remedial Investigation of the Upper East Fork Poplar Creek Characterization Area at the Oak Ridge Y-12 Plant. DOE/OR/01-1641/V1-V4\&D2. Oak Ridge, Tennessee.

DOE (US Department of Energy). 2001. Treatability Study Report for Evaluating the Upper East Fork Poplar Creek Hydraulic Connection at the Y-12 National Security Complex, Oak Ridge, Tennessee. DOE/OR/01-1963\&D1. Office of Environmental Management, Oak Ridge, Tennessee.

DOE (US Department of Energy). 2002. Record of Decision for Phase I Interim Source Control Actions in the Upper East Fork Poplar Creek Characterization Area, Oak Ridge, Tennessee. DOE/OR/011951\&D3. Oak Ridge, Tennessee.

DOE (US Department of Energy). 2004. Remediation Effectiveness Report for the U.S. Department of Energy Oak Ridge Reservation, Oak Ridge, Tennessee. DOE/OR/01-2133\&D1. Office of Environmental Management, Oak Ridge, Tennessee.

Lockheed Martin Energy Systems, Inc. 1997. Mercury Abatement Report for the U.S. Department of Energy Oak Ridge Y-12 Plant for Fiscal Year 1997. Y/ER-297.

Moline, G. R., Southworth, G. R., Bogle, M. A., and Field, S. 2001. Upper East Fork Poplar Creek hydrologic assessment: Tracer test result. Letter Report. Oak Ridge, Tennessee.

Moline, G. R., Southworth, G. R., Bogle, M. A., Watson, D. B., and Field, S. 1998. An Investigation of Increased Mercury Loading in Upper East Fork Poplar Creek During Flow Management: Probable Causes and Links to Subsurface Hydrology. ORNL/TM-13644. Oak Ridge National Laboratory, Oak Ridge, Tennessee.

ORISE (Oak Ridge Institute for Science and Education). 2010. Characterization Report for the 81-10 Area in the Upper East Fork Poplar Creek Area at the Oak Ridge Y-12 National Security Complex, Oak Ridge, Tennessee. DOE/OR/01-2485\&D1. Oak Ridge, Tennessee.

Peterson, M. J., Looney, B., Southworth, G., Eddy-Dilek, C., Watson, D., Ketelle, R., and Bogle, M. 2011. Conceptual Model of Primary Mercury Sources, Transport Pathways, and Flux at the Y-12 Complex and Upper East Fork Poplar Creek, Oak Ridge, Tennessee. ORNL/TM-2011/75. Oak Ridge National Laboratory, Oak Ridge, Tennessee.

Riscassi, A. L., Miller, C., and Brooks, S. C. 2016. "Seasonal and flow-driven dynamics of particulate and dissolved mercury and methylmercury in a stream impacted by an industrial mercury source." Environmental Toxicology and Chemistry 35(6): 1386-1400. doi:10.1002/etc.3310 
Rothschild, E. R., Turner, R. R., Stow, S. H., Bogle, M. A., Hyder, L. K., Sealand, O. M., and Wyrick, H. J. 1984. Investigation of Subsurface Mercury at the Oak Ridge Y-12 Plant. ORNL/TM9092. Oak Ridge National Laboratory, Oak Ridge, Tennessee.

Southworth, G., Bogle, M. A., Brooks, S., Liang, L., Peterson, M., Spalding, B., Watson, D., Zhang, F., and Abraham, T. 2010a. Evaluation of New Options for Reducing Mercury Release at the Y-12 National Security Complex. ORNL/TM-2010/33. Oak Ridge National Laboratory, Oak Ridge, Tennessee.

Southworth, G., Brooks, S., Peterson, M., Bogle, M. A., Miller, C., Elliott, M., and Liang, L. 2009. Controlling Mercury Release from Source Zones to Surface Water: Initial Results of Pilot Tests at the Y-12 National Security Complex. ORNL/TM-2009/035. Oak Ridge National Laboratory, Oak Ridge, Tennessee.

Southworth, G., Greeley, M., Peterson, M., Lowe, K., and Ketelle, R. 2010b. Sources of Mercury to East Fork Poplar Creek Downstream from the Y-12 National Security Complex: Inventories and Export Rates. ORNL/TM-2009/231. Oak Ridge National Laboratory, Oak Ridge, Tennessee.

Turner, R. R., Kamp, G. E., Bogle, M. A., Switek, J., and McElhaney, R. 1985. Sources and discharges of mercury in drainage waters at the Oak Ridge Y-12 Plant. Y/TS-90. Oak Ridge Y-12 Plant, Oak Ridge, Tennessee.

Watson, D. B., Brooks, S. C., Mathews, T. J., Bevelhimer, M. S., DeRolph, C. R., Brandt, C., Peterson, M. J., and Ketelle, R. 2016. Evaluation of Lower East Fork Poplar Creek Mercury Sources. ORNL/TM-2016/134. Oak Ridge National Laboratory, Oak Ridge, Tennessee. 